\title{
Recombinant Toxoplasma gondii Ribosomal Protein P2 Modulates the Functions of Murine Macrophages In Vitro and Provides Immunity against Acute Toxoplasmosis In Vivo
}

\author{
Zhengqing Yu ${ }^{1}$, Yujia Lu ${ }^{1}$, Zhaoyi Liu ${ }^{1}$, Muhammad Tahir Aleem ${ }^{1}$, Junlong Liu ${ }^{2}$, Jianxun Luo ${ }^{2}$, Ruofeng Yan ${ }^{1}$, \\ Lixin $\mathrm{Xu}^{1}$, Xiaokai Song ${ }^{1}$ and Xiangrui $\mathrm{Li}^{1, * \mathbb{D}}$ \\ 1 MOE Joint International Research Laboratory of Animal Health and Food Safety, College of Veterinary \\ Medicine, Nanjing Agricultural University, Nanjing 210000, China; 2018207044@njau.edu.cn (Z.Y.); \\ 11118310@njau.edu.cn (Y.L.); 17118306@njau.edu.cn (Z.L.); 2018207076@njau.edu.cn (M.T.A.); \\ yanruofeng@njau.edu.cn (R.Y.); xulixin@njau.edu.cn (L.X.); songxiaokai@njau.edu.cn (X.S.) \\ 2 State Key Laboratory of Veterinary Etiological Biology, Key Laboratory of Veterinary Parasitology of Gansu \\ Province, Lanzhou Veterinary Research Institute, Chinese Academy of Agricultural Sciences, \\ Lanzhou 730046, China; liujunlong@caas.cn (J.L.); luojianxun@caas.cn (J.L.) \\ * Correspondence: lixiangrui@njau.edu.cn; Tel.: +86-025-8439-9000
}

Citation: Yu, Z.; Lu, Y.; Liu, Z.; Aleem, M.T.; Liu, J.; Luo, J.; Yan, R.; $\mathrm{Xu}$, L.; Song, X.; Li, X. Recombinant Toxoplasma gondii Ribosomal Protein P2 Modulates the Functions of Murine Macrophages In Vitro and Provides Immunity against Acute Toxoplasmosis In Vivo. Vaccines 2021, 9, 357. https://doi.org/10.3390/ vaccines 9040357

Academic Editor: Ernesto

S. Nakayasu

Received: 7 March 2021

Accepted: 6 April 2021

Published: 7 April 2021

Publisher's Note: MDPI stays neutral with regard to jurisdictional claims in published maps and institutional affiliations.

Copyright: (c) 2021 by the authors. Licensee MDPI, Basel, Switzerland. This article is an open access article distributed under the terms and conditions of the Creative Commons Attribution (CC BY) license (https:// creativecommons.org/licenses/by/ $4.0 /)$

\begin{abstract}
Almost every warm-blooded animal can be an intermediate host for Toxoplasma gondii (T. gondii); there is still no efficient vaccine and medicine available for T. gondii infections. Detected on the surface of free tachyzoites of T. gondii, T. gondii ribosomal protein P2 (TgRPP2) has been identified as a target for protection against toxoplasmosis. In the present study, TgRPP2 was firstly expressed in a prokaryotic expression system, and the purified recombinant TgRPP2 (rTgRPP2) was characterized by its modulation effects on murine macrophages. Then, the purified rTgRPP2 was injected into mice to evaluate the immune protection of rTgRPP2. The results indicated that rTgRPP2 could bind to murine Ana-1 cells and showed good reactogenicity. After incubation with purified rTgRPP2, the proliferation, apoptosis, phagocytosis, nitric oxide (NO) production, and cytokines secreted by murine macrophages were modulated. Furthermore, the in vivo experiments indicated that animals immunized with rTgRPP2 could generate a significantly high level of antibodies, cytokines, and major histocompatibility complex (MHC) molecules, leading to a prolonged survival time. All of the results indicated that murine macrophages could be regulated by rTgRPP2 and are essential for the maintenance of tissue homeostasis. Immunization with rTgRPP2 triggered significant protection, with prolonged survival time in a mice model of acute toxoplasmosis. Our results lend credibility to the idea that rTgRPP2 could be a potential target for drug design and vaccine development.
\end{abstract}

Keywords: Toxoplasma gondii; ribosomal protein P2; murine macrophage; immune protection

\section{Introduction}

Toxoplasma gondii (T. gondii) is an obligate intracellular parasite belonging to the phylum Apicomplexa. It can infect a wide range of warm-blooded animals, exhibiting zoonotic potential and being responsible for human toxoplasmosis [1,2]. According to a conservative estimation, more than 1 billion people have been infected around the world [2,3]. Opportunistic parasites are usually symbiotic organisms that become pathogenic in specific conditions, mainly in immunocompromised hosts (e.g., AIDS patients). T. gondii is not an opportunistic pathogen; it is a true pathogen that can cause disease itself, even without favorable conditions [4]. Normally, immunocompetent patients do not display symptoms. However, these parasites can cause severe disease, even leading to death in immunocompromised individuals [5]. According to previous reports, T. gondii can be spread by the ingestion of unsterilized meat and contaminated fruits, vegetables, and drinking water [6-8]. Moreover, the vertical transmission of T. gondii can cause irreversible damage to a fetus, miscarriage, and stillbirth; additionally, congenital deformities can occur [9-12]. 
Currently, there are no effective vaccines and treatments for T. gondii. Based on the T. gondii S48 strain, a live attenuated vaccine (Ovilis Toxovax ${ }^{\circledR}$, Intervet, Angers, France) has been approved for sheep and goats [13]. However, the toxicity, mechanism, and stability of Ovilis Toxovax®still need to be improved. Pyrimethamine (PYR) and sulfadiazine (SDZ) have been approved for the treatment of toxoplasmosis. However, these two drugs can only depress Toxoplasma folate synthesis [14] and do not affect the bradyzoites, suggesting that they cannot eliminate chronic infection [15]. Moreover, the side effects, such as kidney disorders, immunosuppression, and teratogenicity in the fetus, are also obvious $[16,17]$. Conclusively, the development of an effective prevention and treatment therapy against toxoplasmosis is an urgent and important requirement.

Cell immunity reaction is an efficient way for hosts to resist $T$. gondii [18]. The activated macrophages have been divided into two main phenotypes: classically activated macrophages (M1) and alternatively activated macrophages (M2) $[19,20]$. An increasing number of reports have suggested that macrophages in different phenotypes present different functions in the inflammatory response and tissue repair [21,22]. Many proinflammatory agents are generated during early and acute T. gondii invasion, and, largely, cytokines are released. Cytokine IFN- $\gamma$ can efficiently activate M1 macrophages through the NF- $\mathrm{KB}$ signaling pathway and promote M1 macrophages to secrete proinflammatory cytokines (IL-1 $\beta$, TNF- $\alpha$, IL-6, and IL-23), inducible nitric oxide synthase (iNOS), and nitric oxide (NO), even enhancing the ability of phagocytes to resist $T$. gondii $[23,24]$. Interestingly, although macrophages play an important role in resisting the replications of T. gondii [25], T. gondii has developed multistrategies to limit the antimicrobial activities of macrophages $[26,27]$. Thus, developing an appropriate and efficient target may prove a highly efficacious strategy in the development of T. gondii vaccines.

As is known, a complete ribosome is composed of a large subunit (LSU) and a small subunit (SSU). In eukaryotes, P-proteins comprise the large subunit, with the P0 protein in the center, finally forming the stalk $\mathrm{P} 0-(\mathrm{P} 1-\mathrm{P} 2)_{2}$ complex with the ribosomal proteins P1 and P2 [28]. Ribosomes and mitoribosomes are considered to have a fundamental role in parasite biology. According to previous reports, some genes encoding mitochondrial protein are crucial for the survival of T. gondii [29]. Based on this fact, mitochondria and mitoribosomes have been the focus of drug and vaccine discovery research [30-32], and there is evidence that ribosomal proteins are promising targets for anti-T. gondii infections [33]. A recent study showed that the ribosomal P2 protein and the P protein pentamer complex were immunogenic in Plasmodium falciparum [34], and the P2 protein from P. falciparum was highly homologous to the T. gondii RPP2 protein (TgRPP2). Unlike the ribosomal P2 protein of P. falciparum [35,36], the TgRPP2 protein has been demonstrated to exist on the surface of $T$. gondii tachyzoites using the immunohistochemical method; however, the TgRPP2 protein was not observed on the surface of human foreskin fibroblast (HFF) cells during T. gondii infections in vitro [33]. This finding strengthens the hypothesis that TgRPP2 could be involved in T. gondii invasion. Therefore, it could be a potential target for effective prevention and treatment therapy against $T$. gondii. Although signal and transmembrane domains have not been reported for the TgRPP2 protein [35], there are still some reports suggesting that TgRPP2 might be involved as an invasion ligand, which could help T. gondii adhere to host cells [37].

Using a prokaryotic expression system to further explore how recombinant TgRPP2 (rTgRPP2, Uniprot ID: A0A125YFT4) modulates host immunity, we employed an unbiased approach to investigate the potential effects of rTgRPP2 on murine macrophages in vitro and immune protection against acute toxoplasmosis in vivo. The in vitro results showed that rTgRPP2 could enhance proliferation, expedite apoptosis, stimulate phagocytosis, promote NO secretion, and modulate cytokine secretion. The in vivo results revealed that rTgRPP2 could provide immune protection and prolong survival time against a lethal challenge with the virulent RH strain of T. gondii. All these results indicate that Toxoplasma ribosomal protein $\mathrm{P} 2$ could be a good candidate for $T$. gondii prevention and treatment. 


\section{Materials and Methods}

\subsection{Animals, Parasites, and Cultured Cells}

Sprague Dawley (SD) rats (male), weighing 200-220 g, were bought from the Center of Comparative Medicine, Yangzhou University, China, and grown in a specific pathogen-free environment. T. gondii type I (RH strain) was kept in the Ministry of Education (MOE) Joint International Research Laboratory of Animal Health and Food Safety, College of Veterinary Medicine, Nanjing Agricultural University, Nanjing, Jiangsu, PR China. To maintain these parasites, previous methods described by Zhao were conducted [38]. The mouse cell line of Ana-1 macrophages, which was received from the Institute of Cell Biology, Chinese Academy of Sciences (Shanghai, China), was cultivated in Roswell Park Memorial Institute 1640 (RPMI 1640) culture medium supplemented with heat deactivated 10\% FBS (fetal bovine serum, Gibco, Grand Island, NY, USA), with $1 \%$ penicillin/streptomycin at $37{ }^{\circ} \mathrm{C}$ in a $\mathrm{CO}_{2}(5 \%)$ standard atmosphere.

\subsection{Cloning and Molecular Characterization of TgRPP2}

In accordance with the manufacturer's manual, Trizol reactant (Invitrogen, Shanghai, China) was applied to extract the whole RNA from tachyzoites of T. gondii. After this, cDNA was manufactured by utilizing the cDNA Kit (Takara Biotechnology, Dalian, China) and retained at $-80^{\circ} \mathrm{C}$. Primers were prepared and designed based on the coding sequence (CDS) of the TgRPP2 gene (GeneBank: XM_002364187). Restraint endonuclease Eco RI and Hind III (Takara Biotechnology, Dalian, China) were placed in sense and antisense primers successively, and homologous sequences were also included, following the manufacturer's guidance (Vazyme Biotech, Nanjing, China). The sense and antisense primers, ${ }^{\prime}$-GCTGATATCGGATCC GAATTC ATGGCAATGAAATACTTCGCTG- ${ }^{\prime}$ ' and 5'-CTCGAGTGCGGCCGC AAGCTT TTAGTCGAAGAGCGAGAAGCCC-3', targeting the complete $342 \mathrm{bp}$ TgRPP2 open reading frame (ORF), were obtained from Tsingke Biological Technology (Nanjing, China). The amplification reaction mixture consisted of 1.25 U EX Taq (Takara Biotechnology, Dalian, China), $5 \mu \mathrm{L} 10 \times$ Ex Taq buffer, $4 \mu \mathrm{L}$ dNTP mixtures ( $\mathrm{Mg}^{2+}$ plus), $20 \mathrm{pmol}$ of both primers, and a 2-ng cDNA model in a final volume of $50 \mu \mathrm{L}$. The PCR condition was $95{ }^{\circ} \mathrm{C}$ for $5 \mathrm{~min}$, followed by 35 cycles of $95{ }^{\circ} \mathrm{C}$ for $30 \mathrm{~s}$, $62{ }^{\circ} \mathrm{C}$ for $30 \mathrm{~s}$, and $72{ }^{\circ} \mathrm{C}$ for $1 \mathrm{~min}$, and the last extension step at $72{ }^{\circ} \mathrm{C}$ for $5 \mathrm{~min}$. Then, the PCR products were electrophoresed in a 1.0\% tris-borate-EDTA (TBE) buffer and stained with Goldview (Solarbio, Beijing, China). The amplicons were visualized under UV light and purified by the E.Z.N.A. Gel-Extraction Kit (Omega Biotech, Norcross, GA, USA), according to the manufacturer's directions. Finally, the amplicons were subcloned into a linear pET32a vector (Takara Biotechnology, Dalian, China) that had been digested by restriction endonucleases Eco RI and Hind III using the One Step Cloning Kit (Vazyme Biotech, Nanjing, China). After that, recombinant plasmid pET32a/TgRPP2 was transformed into DH5 $\alpha$ (Invitrogen Biotechnology, Shanghai, China) and cultivated in Luria Bertani culture medium (LB) with a dosage of $100 \mu \mathrm{g} / \mathrm{mL}$ ampicillin. The recombinant plasmid pET32a/TgRPP2 was then determined by double enzyme digest and sequenced on an ABI PRISM ${ }^{\mathrm{TM}} 3730$ XL DNA analyzer (Applied Biosystems, Carlsbad, CA, USA) by Tsingke Biological Technology (Nanjing, China). Sequence analysis was also conducted using the online Blast system (https://blast.ncbi.nlm.nih.gov/Blast.cgi, accessed on 6 April 2021).

\subsection{Expression and Purification of Recombinant TgRPP2 and the $p E T 32 a$ Vector Protein}

The verified recombinant plasmid was isolated under the guidance of the PlasmidMini Kit (Omega Biotech, Norcross, GA, USA) and transformed into Escherichia coli BL21 (DE3) (Invitrogen Biotechnology, Shanghai, China). To obtain the pET32a vector protein, the circular pET32a obtained from the dealers was also transformed into E. coli BL21 (DE3). Recombinant TgRPP2 and the pET32a vector protein were expressed under the induction of $1 \mathrm{mM}$ isopropyl- $\beta$-D-thiogalactopyranoside (IPTG; Sigma-Aldrich, Shanghai, China) and purified with a chelating nickel column (Ni-NTA, GE Healthcare, Piscataway, NJ, 
USA) in accordance with the instructions. The recombinant protein was verified by $12 \%$ sodium salt polyacrylamide gel electrophoresis (SDS-PAGE) and stained with Coomassie blue. Endotoxins in the recombinant protein were removed according to the directions of the ToxinEraser ${ }^{\mathrm{TM}}$ Endotoxin Removal Kit (GeneScript, Piscataway, NJ, USA). Before further analysis, the ToxinSensor ${ }^{\mathrm{TM}}$ Chromogenic LAL Endotoxin Assay Kit (GeneScript, Piscataway, NJ, USA) was also used to detect the level of endotoxins in the recombinant proteins. The concentration of recombinant protein was also determined by using the Pierce $^{\mathrm{TM}}$ BCA Protein Assay Kit (Thermo Scientific, Waltham, MA, USA). Briefly, $25 \mu \mathrm{L}$ of each standard or recombinant protein was added into a microplate well; then, $200 \mu \mathrm{L}$ of working reagent ( 50 part "Reagent $\mathrm{A}^{\text {" }}$ and 1 part "Regent $\mathrm{B}$ ") was added to each well and mixed in the microplate thoroughly. After incubation at $37^{\circ} \mathrm{C}$ for $30 \mathrm{~min}$ in the dark, protein concentration was measured by measuring the absorbance at $562 \mathrm{~nm}$ using a plate reader (Thermo Scientific, Waltham, MA, USA).

\subsection{Total Soluble Protein of T. gondii Tachyzoites}

The purified T. gondii tachyzoites were collected in $1 \mathrm{~mL} \mathrm{pH} 7.4$ phosphate buffer solution. After three freeze-thaw steps, the tachyzoites were then crushed by sonication at a continuous mode for $2 \mathrm{~s}$ at $4 \mathrm{~s}$ intervals ( $8 \mathrm{~min}$ in total) under high power $(60 \mathrm{~W})$ on ice. A RIPA solution (Thermo Scientific, Waltham, MA, USA) and a proteinase inhibitor (Thermo Scientific, Waltham, MA, USA) were then added for the complete lysis of proteins. The solution, consisting of the total soluble protein of T. gondii tachyzoites, was collected by high-speed centrifugation at $12,000 \mathrm{r} / \mathrm{min}$ for $30 \mathrm{~min}$ at $4{ }^{\circ} \mathrm{C}$. Then, the supernatant was determined using the bicinchoninic acid method (BCA) mentioned above.

\subsection{Western Blot Analysis of the pET32a Vector Protein, Recombinant, and Native TgRPP2}

To obtain serum from SD rats immunized by rTgRPP2, $200 \mu \mathrm{g}$ of purified rTgRPP2 was emulsified with an equal volume of Freund's complete adjuvant (Sigma-Aldrich, Saint Louis, USA) to produce an emulsion vaccine, and the SD rats were then immunized with the emulsion vaccine as the first injection. Applying two-week intervals, the emulsion mixture, composed of $200 \mu \mathrm{g}$ purified rTgRPP2 and an equal volume of Freund's incomplete adjuvant (Sigma-Aldrich, Saint Louis, MO, USA), was injected into rats as the second to fourth injections. All immunized emulsions were subcutaneously delivered into the back skin of rats. Whole blood was collected from the orbit one week after the last immunization, and the serum was then separated.

The $T$. gondii infection serum was also harvested from SD rats artificially challenged with $5 \times 10^{5} \mathrm{~T}$. gondii tachyzoites by intra-abdominal infection three weeks before. Blank serum was also harvested from the SD rats as the negative control. All the serums were kept at $-20{ }^{\circ} \mathrm{C}$ until use, and all of the SD rats were kept in the same environment. T. gondii lysates were also prepared, as previously described [39].

The purified recombinant TgRPP2 protein, pET32a vector protein, and T. gondii lysates were first separated by $12 \%$ SDS-PAGE gel and then transferred to a polyvinylidene difluoride (PVDF) membrane (Immobilon-PSQ, Millipore, Billerica, MA, USA). Initially, a blocking buffer containing $5 \%(w / v)$ skimmed milk powder dissolved in TBST (TBS containing $0.5 \%$ Tween 20) was used to block nonspecific binding sites at $37^{\circ} \mathrm{C}$ for $2 \mathrm{~h}$. Then, after being bathed in TBST three times, the membrane was incubated in primary antibodies (1:100 dilution, different sera collected from rats) at $37^{\circ} \mathrm{C}$ for $2 \mathrm{~h}$. Diluted at 1:5000, according to the guidelines of instruction, the membrane was then incubated with HRP-conjugated goat anti-rat IgG (eBioscience, San Diego, CA, USA) in TBST at $37^{\circ} \mathrm{C}$ for $1 \mathrm{~h}$, after being washed three times in TBST. To detect $\mathrm{pET32a}$ vector protein, purified recombinant TgRPP2 protein and $\mathrm{pET} 32 \mathrm{a}$ vector protein were also analyzed by the mouse anti-His-tagged antibody (Proteintech Group, Rosemont, IL, USA) and HRP-conjugated goat anti-mouse IgG (Biosharp life sciences, Hefei, China) as the primary and secondary antibodies. Finally, the membrane was stained with freshly prepared 3,3'-diaminobenzidine (DAB, Sigma-Aldrich, Saint-Louis, MO, USA) to identify the bound antibodies. 


\subsection{Confirmation of $r$ TgRPP2 Binding with Murine Macrophages}

In order to verify the combination ability of recombinant TgRPP2 with murine macrophages, $1 \times 10^{6}$ Ana- 1 cells were collected in a 12-well plate (Costar, Cambridge, MA, USA) and incubated with phosphate-buffered solution (PBS), pET32a vector protein $(20 \mu \mathrm{g} / \mathrm{mL})$ and $\mathrm{rTgRPP} 2(20 \mu \mathrm{g} / \mathrm{mL})$ at $37^{\circ} \mathrm{C}$ for $1 \mathrm{~h}$. After being washed three times in PBS to remove uncombined protein, the cells were then sequentially exposed to the sera from rats immunized by rTgRPP2 (1:100 dilutions) and mouse anti-rat IgG tagged with FITC (1:500 dilution; eBioscience, San Diego, CA, USA); each incubation step was performed at $37^{\circ} \mathrm{C}$ for $15 \mathrm{~min}$. After having been bathed in PBS three times to remove the uncombined antibodies, the murine macrophages were then analyzed by flow cytometry (Beckman Coulter, Brea, CA, USA). Forward scatter (FSC) and side scatter (SSC) were taken to gate the macrophage subsets [40]. Based on the circled cells, a linear gate was then determined according to the blank samples (PBS group). The independent experiments were repeated three times, and each sample was tested once. The percentage was then calculated.

\subsection{Cell Proliferation Detection Assay}

The Ana- 1 cells were diluted to $5 \times 10^{5}$ cells per well in a 96-well plate. After having been incubated with PBS, pET32a vector protein $(20 \mu \mathrm{g} / \mathrm{mL})$, and $\mathrm{rTgRPP} 2$ at different concentrations $(0,5,10,20,40$, and $80 \mu \mathrm{g} / \mathrm{mL})$ for $48 \mathrm{~h}$ at $37^{\circ} \mathrm{C}$, respectively, each well was loaded with the CCK-8 reagents provided by Cell Counting Kit-8 (Beyotime, Shanghai, China). They were cocultured continuously for $2 \mathrm{~h}$, and cell proliferation was then conducted with absorbance using a microplate spectrophotometer at $450 \mathrm{~nm}$ (OD450).

\subsection{Detection of Cell Apoptosis}

The Ana- 1 cells were diluted to $1 \times 10^{6}$ cells/well in a 12-well plate and preincubated with rTgRPP2 $(0,5,10,20,40$, and $80 \mu \mathrm{g} / \mathrm{mL})$, pET32a vector protein $(20 \mu \mathrm{g} / \mathrm{mL})$, and PBS at $37^{\circ} \mathrm{C}$ for $48 \mathrm{~h}$. According to the manufacturer's instructions, the Apoptosis Detection Kit (Miltenyi-Biotec, Bergisch Gladbach, Germany) was used to check the apoptosis level in murine macrophages with flow cytometry. Before flow cytometry, a macrophage-specific gate was determined by FSC and SSC using the same method mentioned in Section 2.6, and a cross gate was then determined according to the fluorescence minus one (FMO) control.

\subsection{FITC-dextran Internalization Assay}

After being diluted to $5 \times 10^{6}$ cells/well in a 12-well plate, the murine Ana- 1 cells were cultured with rTgRPP2 at different concentrations $(0,5,10,20,40$, and $80 \mu \mathrm{g} / \mathrm{mL})$, pET32a vector protein $(20 \mu \mathrm{g} / \mathrm{mL})$, and PBS at $37^{\circ} \mathrm{C}$ for $48 \mathrm{~h}$. The cells were washed in cold PBS three times and then collected in PBS and incubated with FITC-dextran (final concentration was $1 \mathrm{mg} / \mathrm{mL}$, molecular weight 40,000 Da; Sigma-Aldrich, Shanghai, China) at $37^{\circ} \mathrm{C}$ for $1 \mathrm{~h}$. Then, the murine macrophages were washed three times in PBS, and the FITC-dextran internalization was conducted by flow cytometry to demonstrate the effects of rTgRPP2 on the endocytic ability of Ana-1 cells. After the macrophage subsets were gated by FSC and SSC, median fluorescence intensity (MFI) was calculated.

\subsection{Nitric oxide (NO) Production Assay}

To demonstrate the effects of rTgRPP2 on the secretion ability of murine macrophages, Ana- 1 cells were diluted to $5 \times 10^{6}$ cells/well in a 12-well plate and incubated with PBS, pET32a vector protein $(20 \mu \mathrm{g} / \mathrm{mL})$, and $\mathrm{rTgRPP} 2$ at different concentrations $(0,5,10,20,40$, and $80 \mu \mathrm{g} / \mathrm{mL}$ ) for $48 \mathrm{~h}$ at $37^{\circ} \mathrm{C}$. Then, the supernatants of the Ana- 1 cells were collected, and the Total Nitric Oxide Assay Kit (Beyotime, Shanghai, China), based on the Griess assay [41], was used to analyze the secretion of NO by measuring the absorbance values at $540 \mathrm{~nm}(\mathrm{OD} 540)$. 


\subsection{Identification of the Cytokine Level}

According to the manufacturer's principles, double antibody sandwich ELISA kits (Jinyibai, Nanjing, China) were used to measure the secretion levels of tumor necrosis factor- $\alpha$ (TNF- $\alpha$ ), interleukin- $1 \beta$ (IL-1 $\beta$ ), transforming growth factor- $\beta 1$ (TGF- $\beta 1$ ), and interleukin-10 (IL-10) produced by the murine macrophages. Referring to the known quantity of recombinant mouse IL- $1 \beta$, TNF- $\alpha$, IL-10, and TGF- $\beta 1$, standard curves were created. The concentrations of cytokines were measured in the supernatant of the Ana-1 cells mentioned in Section 2.9.

\subsection{Animal Vaccination and Challenge}

To investigate the immune protective properties of $\mathrm{rTgRPP} 2, \mathrm{BALB} / \mathrm{c}$ mice were assigned to three groups ( 25 mice per group) at random. Before vaccination, the recombinant protein was dissolved with PBS (the final concentration was $200 \mu \mathrm{g} / \mathrm{mL}$ ). Every animal was inoculated intramuscularly with $100 \mu \mathrm{L}$ of recombinant protein or PBS alone in the leg at different sites, two times, at Days 0 and 14. Two weeks after the last immunization, all animals were challenged with 200 tachyzoites of the T. gondii RH strain through intraperitoneal injection. The survival time of each animal was observed and recorded daily.

\subsection{Determination of the Levels of Antibodies and Cytokines}

The animals' blood was collected from the eye socket at Days 0, 7, and 14 (whole blood was first collected before immunization), and the sera were then separated at once and kept at $-20^{\circ} \mathrm{C}$ until use.

The levels of antibodies in the sera were investigated by the standard enzyme-linked immunosorbent assay (ELISA) referenced in a previous procedure [42]. In short, the rTgRPP2 protein was firstly dissolved in $50 \mathrm{mM}$ carbonate buffer ( $\mathrm{pH}$ 9.6) to a final concentration of $100 \mu \mathrm{L} / \mathrm{mL}$, and each well of the 96-well plate (Costar, Cambridge, MA, USA) was then coated with $100 \mu \mathrm{L}$ rTgRPP2 overnight at $4{ }^{\circ} \mathrm{C}$. After being washed in PBS containing $0.05 \%$ Tween 20 (PBST) three times, the plate was then blocked with PBST containing $3 \%$ bovine serum albumin (BSA) for $1 \mathrm{~h}$ at $37^{\circ} \mathrm{C}$. The second antibodies HRP-conjugated anti-mouse-IgG, IgG1, and IgG2a (eBioscience, San Diego, CA, USA) were added to investigate the first antibodies in the sera. The immune complex was then incubated with 3,3',5,5'-tetramethylbenzidine (TMB, Tiangen, Beijing, China). Twenty minutes later, the reaction was stopped by adding $2 \mathrm{M}$ newly prepared $\mathrm{H}_{2} \mathrm{SO}_{4}$. The absorbance was then measured at $450 \mathrm{~nm}$ using a microplate photometer (Thermo Scientific, Waltham, MA, USA).

To identify the levels of interferon (IFN) gamma (IFN- $\gamma$ ), IL-4, IL-10, and IL-17 in sera, commercial ELISA kits (Jinyibai, Nanjing, China) were used. Using a microplate photometer, the concentration of cytokines was quantified according to known recombinant mouse cytokines. Each group had five replications, and each serum was quantified once.

\subsection{Major Histocompatibility Complex (MHC) Molecule Analysis}

Mice were euthanized under the supervision of the Animal Ethics Committee, Nanjing Agricultural University, China, and the spleen of each mouse was then collected. A murine lymphocyte separation kit (Solarbio, Beijing, China) was used to obtain the spleen lymphocytes. The obtained cells were randomized into two groups, stained with antimouse CD3e-APC (eBioscience, San Diego, CA, USA) and MHC-I-FITC (eBioscience, San Diego, CA, USA) and anti-mouse CD3e-PE (eBioscience, San Diego, USA) and MHC-II-APC (eBioscience, San Diego, CA, USA), respectively, for $30 \mathrm{~min}$ at $4{ }^{\circ} \mathrm{C}$. After being washed in PBS three times, the harvested cells were analyzed by a flow cytometer (BD Biosciences, Franklin Lakes, NJ, USA) to determine the levels of MHC class I and II molecules. As described by [40], a lymphocyte subset was gated before analysis, and a cross gate of the lymphocyte subset was then determined according to the FMO controls. Each group had five replications, and each sample was quantified once. 


\subsection{Statistical Analysis}

The data are shown as means \pm standard deviation (SD). All of the data analysis processes were conducted using GraphPad 6.0 software (GraphPad Prism, San Diego, CA, USA). The deviations among all groups were estimated as significant at $p<0.05$ using oneway ANOVA followed by Dunnett's test. The flow cytometry analysis was analyzed using Flowjo software (version 10, Franklin Lakes, NJ, USA). The survival rates were analyzed using SPSS 25.0 software (SPSS Inc., Chicago, IL, USA), and differences in the groups were revealed by the Kaplan-Meier survival test and compared based on the log-rank model.

\section{Results}

\subsection{Preparation of the Eukaryotic Expression Plasmid}

Through double restriction enzyme identification, the recombinant plasmid was successfully constructed, theoretically generating $348 \mathrm{bp}$ and $6229 \mathrm{bp}$ fragments in a $1 \%$ agarose gel electrophoretogram (Figure S1a). Sequence analysis and alignment with the Blast program showed that the insert in the plasmid was the open reading frame (ORF) of TgRPP2 (Figure S1b). All the results confirmed that the plasmid pET32a/TgRPP2 was constructed correctly.

3.2. Expression, Purification, and Western Blot Analysis of Recombinant TgRPP2 and the $p E T 32 a$ Vector Protein

The endotoxin levels for purified protein were less than $0.1 \mathrm{EU} / \mathrm{mL}$. The calculated molecular mass of recombinant TgRPP2 was $29.75 \mathrm{kDa}$, including the pET32a vector protein $(18.0 \mathrm{kDa})$ and the native TgRPP2 protein $(11.76 \mathrm{kDa})$. The sodium salt polyacrylamide gel electrophoresis (SDS-PAGE) results indicated that the molecular weight of the recombinant TgRPP2 protein and the pET32a vector protein was approximately 30 and $18 \mathrm{kDa}$, respectively (Figure 1a). The recombinant TgRPP2 and pET32a vector protein could be detected by an anti-His-tagged antibody (Figure 1b), and the Western blot analysis showed that both recombinant and native TgRPP2 could be identified by sera isolated from rats challenged with T. gondii and sera separated from the rats immunized with rTgRPP2 (Figure 1c,d). Furthermore, the pET32a vector protein could be identified by sera isolated from rats immunized with rTgRPP2 but not sera from rats challenged with $T$. gondii or the sera from normal rats (Figure 1c,d). All the results indicated that recombinant TgRPP2 had high immunogenicity and was involved in triggering an immune response.

\subsection{Validation of the Binding Capability of Recombinant TgRPP2 with Murine Macrophages}

The Ana-1 cells preincubated with rTgRPP2 showed a significant right movement, as can be observed in Figure 2. The percentage of Ana-1 cells in Q2 preincubated with rTgRPP2 was $97.47 \pm 0.76 \%$, and it was significantly higher $(p<0.001)$ than the blank $(0.66 \pm 0.41 \%)$ and control $(1.87 \pm 0.11 \%)$ groups. Flow cytometry results indicated that recombinant TgRPP2 could bind on the surface of murine Ana-1 macrophages.

\subsection{Enhanced Proliferation of Murine Macrophages Triggered by Recombinant TgRPP2}

Cell proliferation was assessed and is illustrated in Figure 3. The absorbance values at $450 \mathrm{~nm}$ (OD450) revealed that it was highly increased in Ana-1 cells preincubated with 20,40 , and $80 \mu \mathrm{g} / \mathrm{mL}$ of rTgRPP2. No obvious distinctions $(p>0.05)$ in the blank group treated with PBS and the control group treated with $\mathrm{pET} 32 \mathrm{a}$ vector protein were observed. 


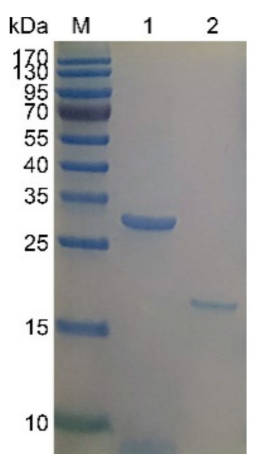

(a)

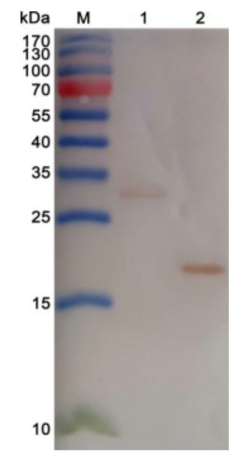

(b)

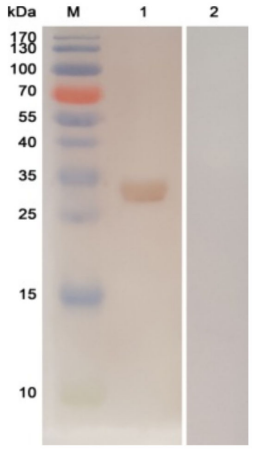

(c)

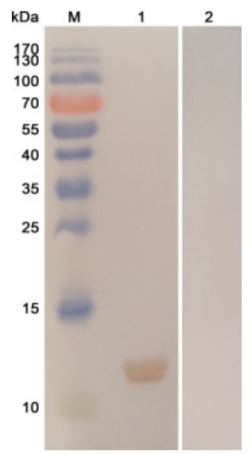

(d)

Figure 1. The results of sodium salt polyacrylamide gel electrophoresis (SDS-PAGE) and Western blot analysis. Line M: protein molecular weight marker. (a) SDS-PAGE analysis of the purified recombinant Toxoplasma gondii ribosomal protein P2 (TgRPP2) and the pET32a vector protein. Line 1: purified recombinant TgRPP2 (rTgRPP2) protein. Line 2: purified pET32a vector protein. (b) Western blotting of recombinant TgRPP2 and the pET32a vector protein. rTgRPP2 (Line 1) and pET32a vector protein (Line 2) probed by a mouse anti-His-tagged antibody as the primary antibody. (c) Western blot of recombinant TgRPP2. Line M: protein molecular weight marker; Line 1: rTgRPP2 probed by serum from rats against T. gondii as the primary antibody; Line 2: rTgRPP2 probed by sera from normal rats as the primary antibody. (d) Western blotting of native TgRPP2. Line M: protein molecular weight marker. Line 1: total soluble protein of $T$. gondii tachyzoites probed by sera from rats immunized by rTgRPP2 as the primary antibody. Line 2: total soluble protein of $T$. gondii tachyzoites probed by sera from normal rats as the primary antibody.

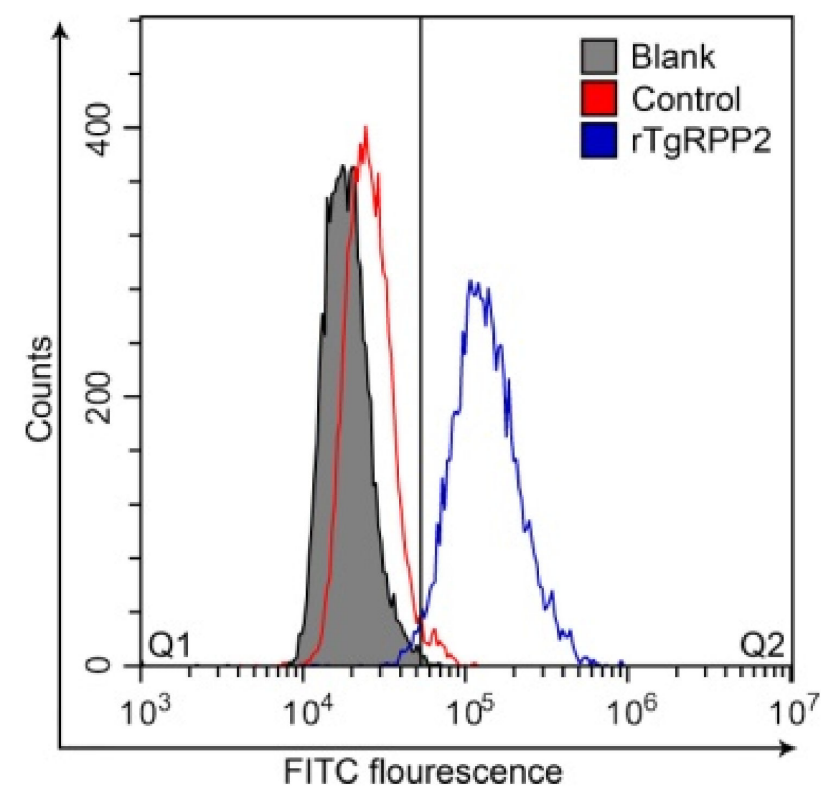

Figure 2. Flow cytometric analysis of rTgRPP2 binding to murine Ana-1 macrophages. In the blank and control groups, the Ana- 1 cells were treated with phosphate-buffered solution (PBS) and pET32a vector protein $(20 \mu \mathrm{g} / \mathrm{mL})$, while the experimental group was treated with purified recombinant TgRPP2 $(20 \mu \mathrm{g} / \mathrm{mL} ; n=3)$. 


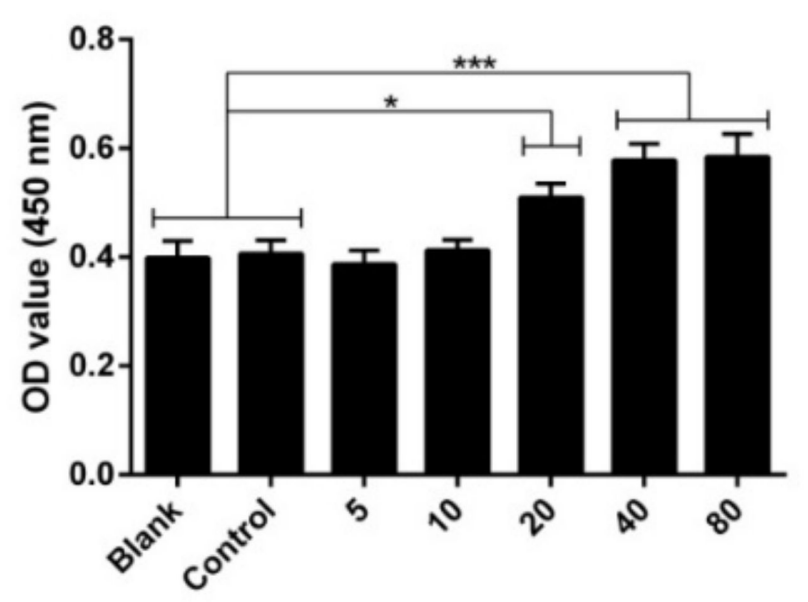

$\operatorname{rTgRPP2}(\mu \mathrm{g} / \mathrm{mL})$

Figure 3. Effects of the proliferation of different concentrations of rTgRPP2 on murine macrophages. The cell proliferation index was calculated by the absorbance values at $450 \mathrm{~nm}$ (OD450) values. The values were evaluated using one-way ANOVA analysis, followed by Dunnett's test, and presented as the mean \pm standard deviation of three independent experiments $(n=3) .{ }^{*} p<0.05$ and *** $p<0.001$ compared with the blank group or the control group.

\subsection{Promoted Apoptosis of Ana-1 Cells Induced by Recombinant TgRPP2}

Early-stage apoptosis is the independently ordered cell death controlled by genes in order to maintain cellular homeostasis, while late-stage apoptosis mainly represents necrotic cells. As illustrated in Figure 4, the results indicate that early-stage apoptosis can be significantly induced $(p<0.001)$ by incubation with rTgRPP2 at the levels of 20,40, and $80 \mu \mathrm{g} / \mathrm{mL}$. As for late-stage apoptosis, a significant difference $(p<0.001)$ was observed in Ana- 1 cells incubated with 10,20,40, and $80 \mu \mathrm{g} / \mathrm{mL}$ recombinant TgRPP2 compared to the blank and control groups. Noticeably, late-stage apoptosis could also be induced $(p<0.05)$ by $5 \mu \mathrm{g} / \mathrm{mL}$ rTgRPP2 compared to the blank group. No statistically significant difference $(p>0.05)$ between the blank group and the control group was recorded.

\subsection{Promoted Phagocytosis in Ana-1 Cells Induced by Recombinant TgRPP2}

To determine the endocytic effects on Ana- 1 cells, a serial dilution of rTgRPP2 was analyzed on FITC-dextran by flow cytometry (Figure 5). The capacity of endocytic functions of Ana- 1 cells was significantly enhanced after culturing with rTgRPP2 at all tested concentrations. In addition, no statistical differences $(p>0.05)$ between the blank group and the control group were detected.

\subsection{Enhanced NO Secretion of Murine Macrophages Triggered by Recombinant TgRPP2}

NO production of murine Ana-1 cells was evaluated and is presented in Figure 6. The Ana- 1 cells could drive significantly higher NO production in response to all concentrations of rTgRPP2. The results also demonstrated that no statistical deviations $(p>0.05)$ between the blank group incubated with PBS and the control group incubated with the pET32a vector protein were observed. 
Early stage apoptosis
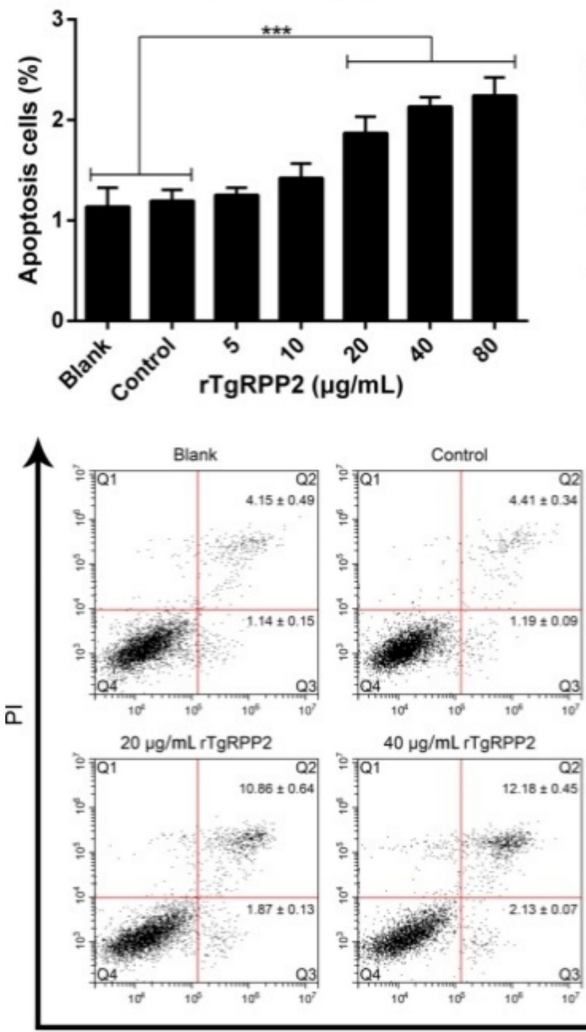

Late stage apoptosis

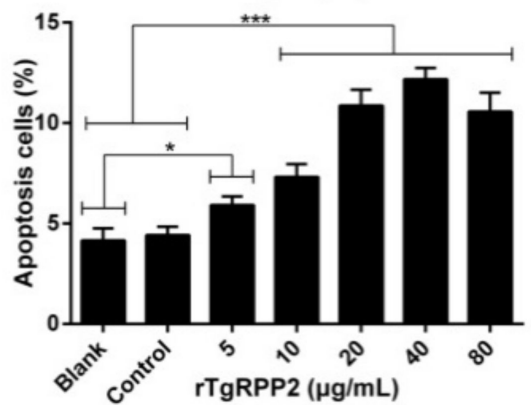

rTgRPP2 $(\mu \mathrm{g} / \mathrm{mL})$

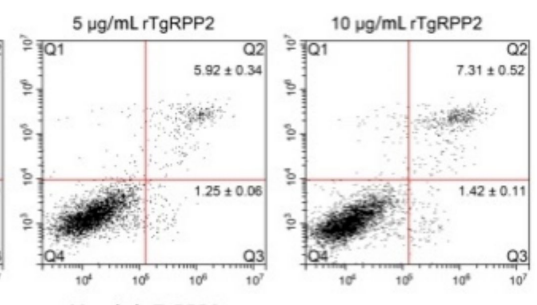

$80 \mu \mathrm{g} / \mathrm{mL} \mathrm{rTgRPP} 2$

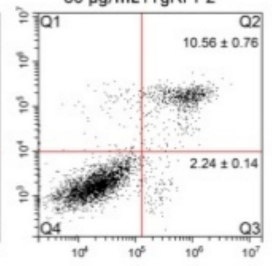

Annexin

Figure 4. Recombinant TgRPP2 induces the apoptosis of murine Ana- 1 cells. Ana-1 cells were preincubated with different concentrations of rTgRPP2 for $48 \mathrm{~h}$. Quadrant Q3 represents earlystage apoptosis (annexin V+/PI-), while quadrant Q2 represents late-stage apoptosis (annexin $\mathrm{V}+/ \mathrm{PI}+$ ). Values were evaluated using one-way ANOVA analysis, followed by Dunnett's test, and expressed as the mean \pm standard deviation of three independent experiments $(n=3) .{ }^{*} p<0.05$ and *** $p<0.001$ compared with the blank group or the control group.

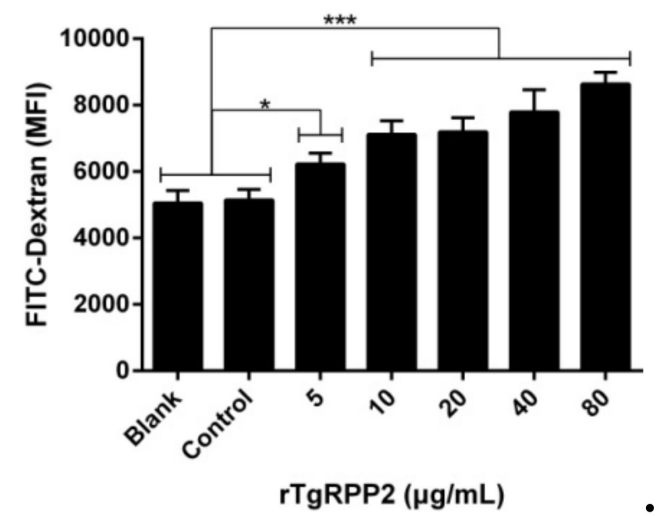

Figure 5. Recombinant TgRPP2 significantly affects the phagocytosis of murine macrophages. Median fluorescence intensity (MFI) was established based on the statistical data. Values were evaluated using one-way ANOVA analysis, followed by Dunnett's test, and presented as the mean \pm standard deviation of three independent experiments $(n=3) .{ }^{*} p<0.05$ and ${ }^{* * *} p<0.001$ compared with the blank group or the control group. 


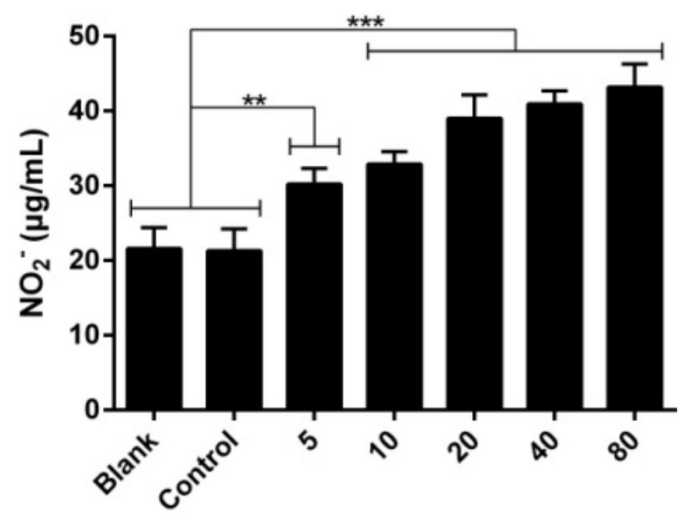

$\operatorname{rTgRPP2}(\mu \mathrm{g} / \mathrm{mL})$

Figure 6. Effect of rTgRPP2 on the NO production of murine Ana-1 cells. Through treatment with different concentrations of rTgRPP2 for $48 \mathrm{~h}$, the NO concentrations were determined. Values were evaluated using one-way ANOVA analysis, followed by Dunnett's test, and presented as the mean \pm standard deviation of three independent experiments $(n=3) .{ }^{* *} p<0.01$ and ${ }^{* * *} p<0.001$ compared with the blank group or the control group.

\subsection{Modulation Effects in the Cytokine Secretion of Murine Macrophages}

To assess the impact on the cytokine secretion of Ana- 1 cells, cytokine levels were measured using the double antibody sandwich ELISA method. When incubated with rTgRPP2, murine macrophages secreted a significantly higher level of proinflammatory cytokines (tumor necrosis factor- $\alpha$ (TNF- $\alpha$ ) and interleukin (IL) $1 \beta$ ). As illustrated in Figure $7 \mathrm{a}, \mathrm{b}$, the secretions of TNF- $\alpha$ were significantly elevated $(p<0.001)$ at all tested concentrations, and the secretions of IL- $1 \beta$ (Figure $7 \mathrm{~b}$ ) were detected at higher levels at concentrations of 40 and $80 \mu \mathrm{g} / \mathrm{mL}$. As demonstrated in Figure $7 \mathrm{c}, \mathrm{d}$, anti-inflammatory cytokines (transforming growth factor- $\beta 1$ (TGF- $\beta 1$ ) and IL-10) were also detected. The TGF- $\beta 1$ secretion of murine Ana- 1 cells was significantly enhanced when incubated with rTgRPP2 at concentrations of 40 and $80 \mu \mathrm{g} / \mathrm{mL}$. Furthermore, the IL- 10 secretion of murine Ana- 1 cells was significantly enhanced $(p<0.01)$ by incubation with $80 \mu \mathrm{g} / \mathrm{mL} \mathrm{rTgRPP} 2$. No obvious significance $(p>0.05)$ was observed in the blank and control groups of the four tested cytokines.

\subsection{Modulation Effects in Antibodies and Cytokine Secretion In Vivo}

To investigate the titers of total IgG and isotypes IgG1 and IgG2a, sera harvested from animals were detected using standard ELISA. As demonstrated in Figure 8a, total IgG antibody titers in the rTgRPP2 group were revealed to be remarkably higher $(p<0.001)$ than the blank and control groups at Days 7 and 14. As illustrated in Figure 8b, animals vaccinated with rTgRPP2 showed significantly higher $(p<0.01)$ isotype IgG1 compared to the blank and control groups at Days 7 and 14. As for IgG2a antibody titers (Figure 8c), animals immunized with rTgRPP2 generated a significantly higher level $(p<0.01)$ compared to the blank and control groups at Days 7 and 14. No significant difference $(p>0.05)$ between the blank and control groups was observed; the detailed titers are displayed in Tables S1 and S2. 


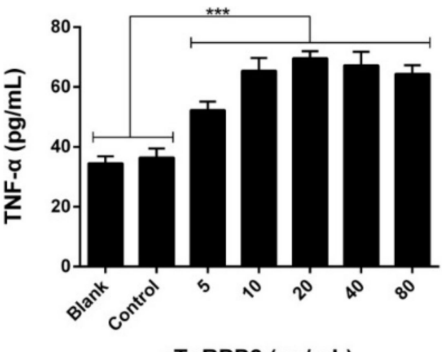

(a)

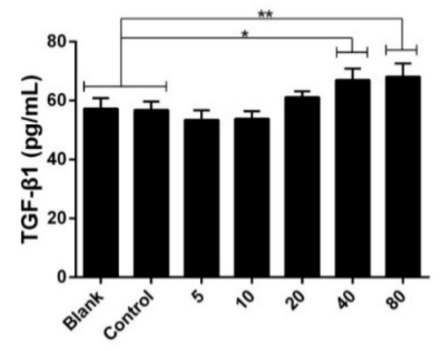

(c)

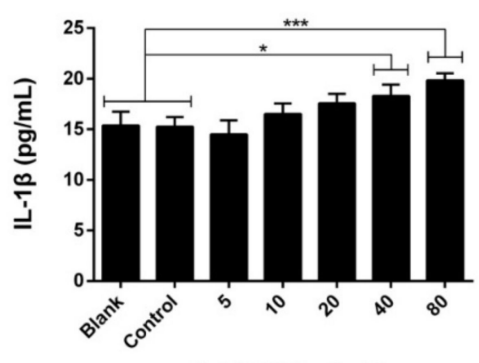

rTgRPP2 $(\mu \mathrm{g} / \mathrm{mL})$

(b)

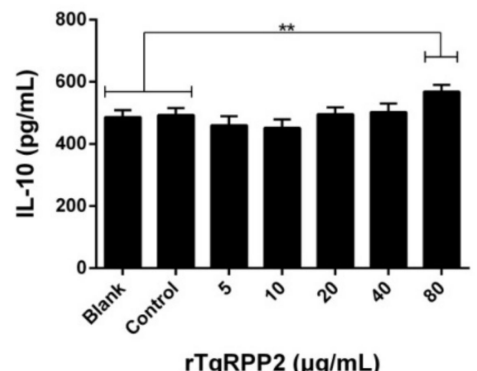

(d)

Figure 7. Effect of recombinant TgRPP2 on tumor necrosis factor- $\alpha$ (TNF- $\alpha)(\mathbf{a})$, interleukin- $1 \beta$ (IL-1 $\beta$ ) (b), transforming growth factor- $\beta 1$ (TGF- $\beta 1$ ) (c), and interleukin-10 (IL-10) (d) secretion of murine Ana- 1 cells. The Ana-1 cells were preincubated with rTgRPP2 at different concentrations for $48 \mathrm{~h}$, and the cytokine secretion was then measured by ELISA kits. Values were evaluated using one-way ANOVA analysis, followed by Dunnett's test, and presented as the mean \pm standard deviation of three independent experiments $(n=3) .{ }^{*} p<0.05$, ${ }^{* *} p<0.01$, and ${ }^{* *} p<0.001$ compared with the blank group or the control group.

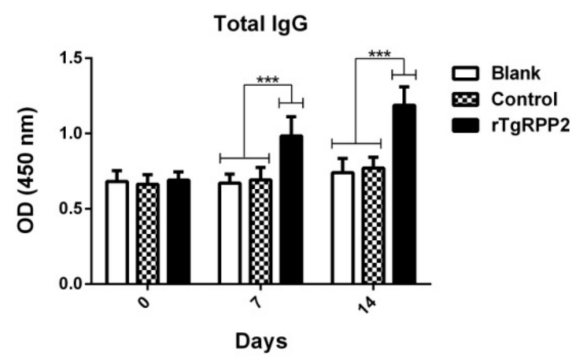

(a)

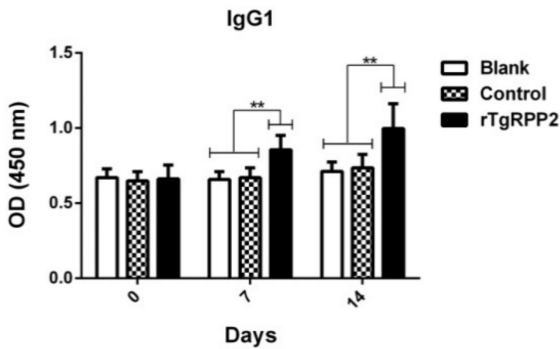

(b)

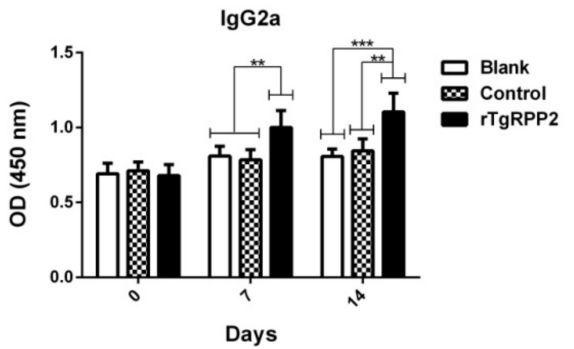

(c)

Figure 8. Determination of total IgG (a) and subclass IgG1 (b) and IgG2a (c) antibodies in the sera from animals vaccinated with PBS, pET32a vector protein, and rTgRPP2. Results were evaluated using one-way ANOVA analysis, followed by Dunnett's test, and shown as the mean of OD450 \pm standard deviation $(n=5) .{ }^{* *} p<0.01$ and ${ }^{* * *} p<0.001$ compared with the blank group or the control group. 
According to the manufacturer's instructions, the secretions of interferon (IFN) gamma (IFN- $\gamma$ ), IL-4, IL-10, and IL-17 in the sera were investigated based on double antibody sandwich ELISA. As shown in Figure 9a,b, a significantly higher level of IFN- $\gamma$ and IL-4 was revealed in animals vaccinated with rTgRPP2 at Days 7 and 14. Additionally, animals immunized with rTgRPP2 only exhibited significantly higher $(p<0.05)$ IL-10 secretion at Day 14 compared to the blank and control groups (Figure 9c). As for IL-17, shown in Figure $9 \mathrm{~d}$, no remarkable difference $(p>0.05)$ was obtained among the rTgRPP2, blank, and control groups.

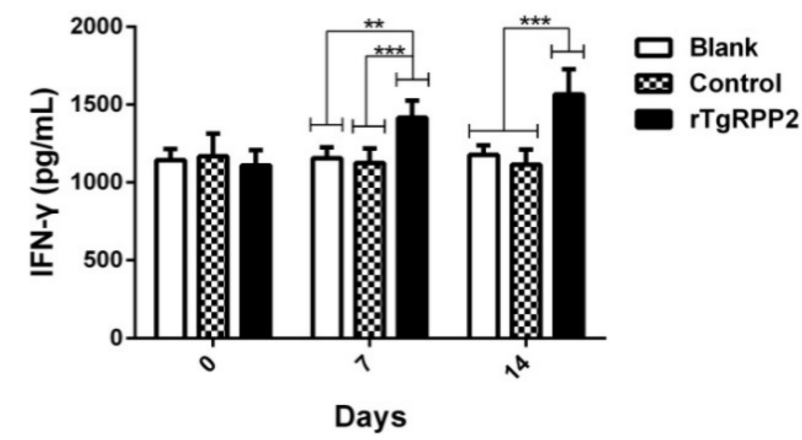

(a)

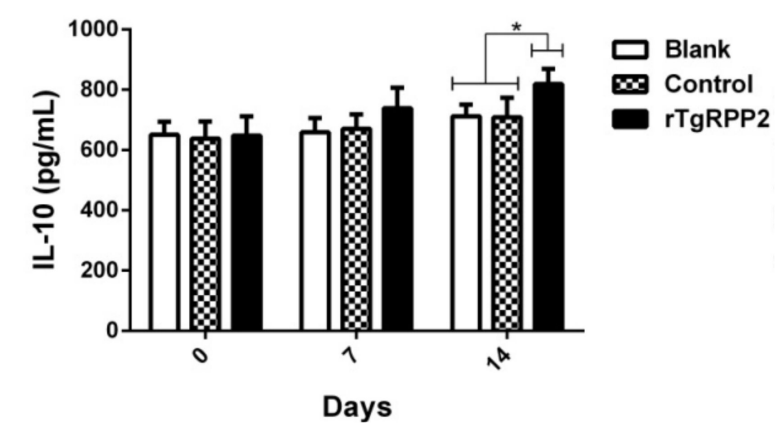

(c)

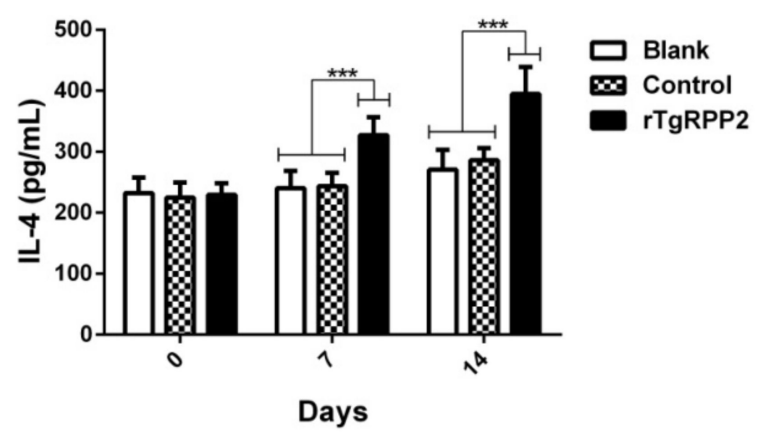

(b)

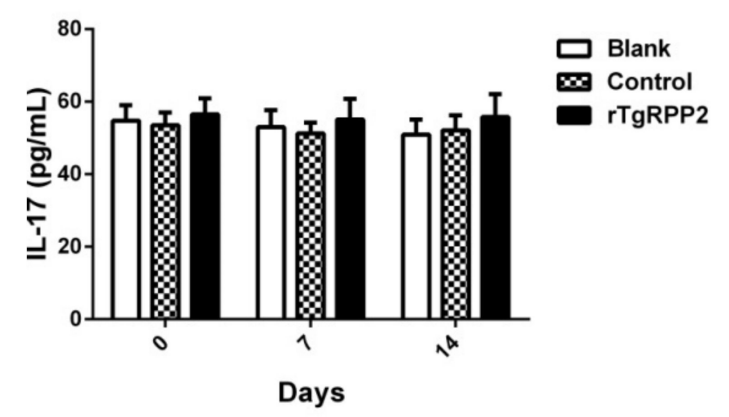

(d)

Figure 9. Cytokine production. Double antibody sandwich ELISA kits were used to determine the level of IFN- $\gamma(\mathbf{a})$, IL-4 (b), IL-10 (c), and IL-17 (d) in sera from animals. Results were evaluated using one-way ANOVA analysis, followed by Dunnett's test, and values are shown as the mean \pm standard deviation $(n=5) .{ }^{*} p<0.05,{ }^{* *} p<0.01$, and ${ }^{* *} p<0.001$ compared with the blank group or the control group.

\subsection{The Major Histocompatibility Complex Molecule Changes in Murine Spleen Lymphocytes}

Flow cytometry analysis was conducted to reveal the major histocompatibility complex (MHC) molecule changes. As illustrated in Figure 10a, a significant percentage $(p<0.001)$ of MHC class I molecules was revealed in animals immunized with rTgRPP2 compared to the blank and control groups at Days 7 and 14. The MHC class II molecules (Figure 10b) also displayed a significant increase $(p<0.01)$ in animals immunized with rTgRPP2 at Days 7 and 14. No significant difference $(p>0.05)$ between the blank and control groups was observed.

\subsection{Immune Protection of Vaccinated Mice against Acute T. gondii Infections}

To investigate the immune protection of rTgRPP2 against acute toxoplasmosis, mice were challenged artificially with 200 tachyzoites of the T. gondii RH strain. As shown in Figure 11, all of the immunized animals succumbed within 16 days. A significant $(p<0.05)$ survival time was revealed in the animals immunized with rTgRPP2 (13.600 \pm 0.777 days) compared to the blank (10.400 \pm 0.718 days) and control (10.300 \pm 0.496 days) groups. Furthermore, no significant difference $(p>0.05)$ between the blank and control groups was observed. 

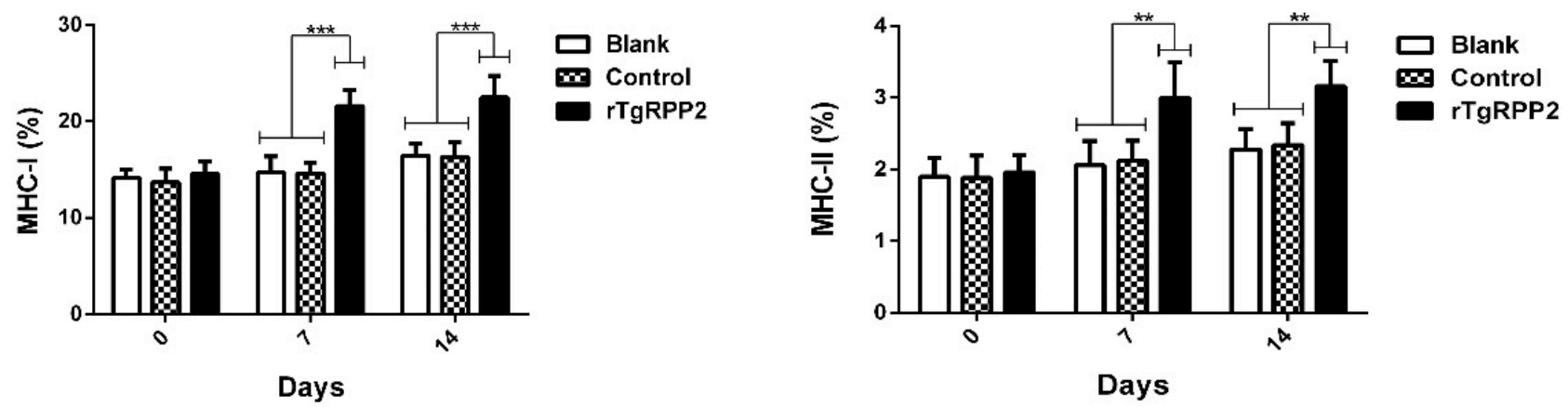

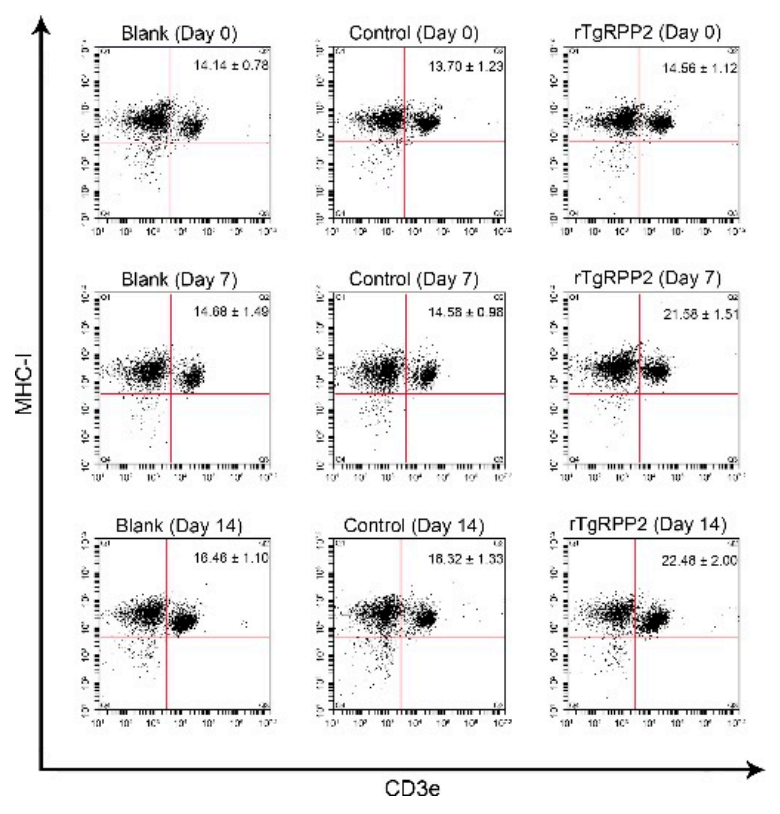

(a)

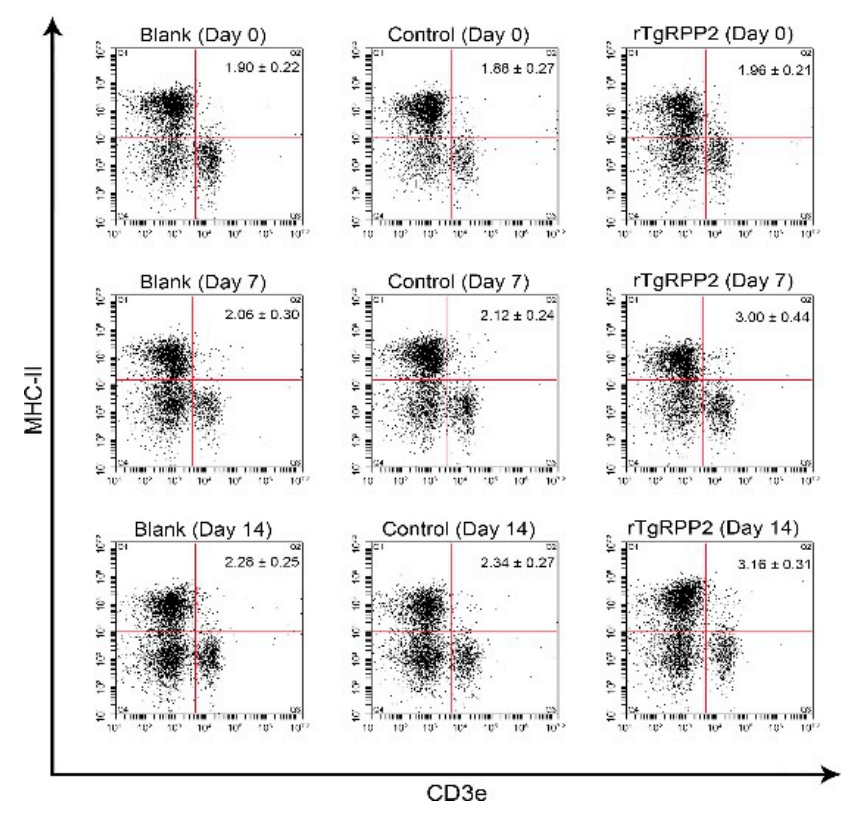

(b)

Figure 10. Flow cytometry analysis of major histocompatibility complex (MHC) class I (a) and MHC class II (b) molecules in murine spleen lymphocytes. Results were evaluated using one-way ANOVA analysis, followed by Dunnett's test, and values are shown as the mean \pm standard deviation $(n=5)$. ${ }^{* *} p<0.01$ and ${ }^{* * *} p<0.001$ compared with the blank group or the control group.

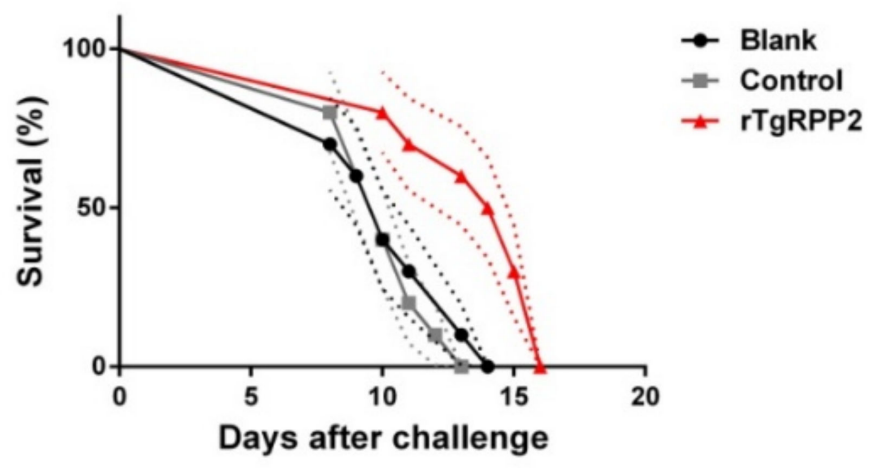

Figure 11. Mice survival rates after challenge infection with the T. gondii RH strain. Results were analyzed by the Kaplan-Meier test and compared based on the log-rank model. Values are shown as the mean \pm standard deviation $(n=10)$. The dotted lines represent standard deviation. 


\section{Discussion}

In the present study, the recombinant TgRPP2 protein is expressed by the prokaryotic expression system. Flow cytometry analysis revealed that rTgRPP2 could bind to the surface of murine macrophages and exhibit their effects. After coincubation with rTgRPP2, cell proliferation and apoptosis of murine Ana- 1 cells were conducted, and the results indicated that $\mathrm{rTgRPP} 2$ could enhance proliferation and expedite apoptosis. The functions of murine macrophages resisting $T$. gondii were subsequently investigated, and endocytic ability and NO secretion were significantly promoted after the samples were cocultured with rTgRPP2. Furthermore, pro- and anti-inflammatory cytokine (TNF- $\alpha$, IL-1 $\beta$, TGF- $\beta 1$, and IL-10) production, exhibited by Ana-1 macrophages, was also investigated, showing the regulation ability of macrophages after incubation with rTgRPP2. The in vivo experiments revealed that rTgRPP2 could trigger immune protection against acute toxoplasmosis. The survival days of the animals immunized with $\mathrm{rTgRPP} 2$ were significantly prolonged. Therefore, all these results reveal that recombinant TgRPP2 can modulate murine macrophages in vitro and can provide immune protection against $T$. gondii in vivo.

As a crucial function of macrophages, phagocytosis can indicate the antimicrobial activities of macrophages from another perspective. In the in vitro experiments, proinflammatory cytokines (TNF- $\alpha$ and IL-1 $\beta$ ) and NO secretions were significantly promoted. In addition, as a commonly used fluorescent probe to determine the permeability and phagocytic activity of cells, FITC-dextran is recognized by macrophages via various pattern recognition receptors (PRRs) [43]. When the recombinant protein combines with the surface of macrophages, the internalization of dextran appears to be promoted by some PRRs. All the results indicate that the anti-T. gondii effects of murine macrophages can be enhanced by rTgRPP2 in vitro. Although M1 macrophages play an important role in suppressing T. gondii, the strong proinflammatory response can lead to tissue injury. M2 macrophages are characterized by the production of anti-inflammatory factors and the demonstration of anti-inflammatory activity $[44,45]$. The anti-inflammatory cytokines (TGF- $\beta 1$ and IL-10) were only enhanced at a high concentration of rTgRPP2, indicating that a high concentration of recombinant protein can lead to immunosuppression. Therefore, a high-dose vaccination of rTgRPP2 should be avoided.

When the host cells were infected by T. gondii, the cell proliferation mechanism of the host cells could be modulated by the parasites [46]. According to previous studies, T. gondii invasion can promote the host and neighboring cells from the G1 phase into the $S$ phase [47]. In the present study, the proliferation of Ana-1 macrophages was enhanced by incubation with recombinant TgRPP2 in vitro. These changes were regarded as beneficial for resisting T. gondii. However, during T. gondii infection, the growth of L6 rat myoblast cells was inhibited, and the proportion of cells remaining in the $\mathrm{S}$ and G2/M phases was increased [48]. After the incubation of recombinant histone 4 and murine macrophages for $24 \mathrm{~h}$, cell proliferation was significantly suppressed [49]. Such a difference can be linked to various incubation times, different types of protein, and even the endotoxin level in the purified protein. More research is needed to further clarify the cell proliferation mechanism.

Most protozoan parasite infections can regulate the apoptosis of host cells, subsequently affecting host cell responses [50]. According to previous studies, apoptosis signaling pathways mainly include the NF- $\mathrm{KB}$ pathway, mitogen-activated protein kinase (MAPKinase) pathways, c-Jun N-terminal kinases (JNKinase) pathways, and PI3K/PKB/Akt pathways [50,51]. In the present study, recombinant TgRPP2 could induce early-stage apoptosis, offering many survival advantages. Late-stage apoptosis was also enhanced, which may have been due to early-stage apoptosis. Different from necrosis, apoptosis is a rational behavior that sacrifices specific cells for more benefits to the organism, a behavior that is highly controlled by genes [52]. According to previous reports, T. gondii has gained the ability to modulate the apoptotic responses of host cells to survive in murine and human cells $[53,54]$. Furthermore, autoantigens derived from early- and late-stage apoptotic cells can induce the activation of T-cells and the expression of B-cells, resulting in 
the enhancement of immunity $[52,55]$. Consequently, the enhanced apoptosis induced by rTgRPP2 could elicit stronger immune protection against $T$. gondii.

The administration dose, route, and strategy play important roles in developing successful immunization [56,57]. In previously published studies, different administration doses, routes, and strategies have been used, but few studies have explained why a definite dose, route, or strategy was chosen. The administration dose has mainly varied from 10 to $200 \mu \mathrm{g}$ per mouse [58-60] in previous studies. In the present study, when incubated with $20 \mu \mathrm{g} / \mathrm{mL}$ recombinant TgRPP2, murine macrophages showed good binding ability with recombinant protein. Furthermore, the murine macrophages exhibited significant proliferation, phagocytosis, NO secretion, and proinflammatory cytokine secretion after incubation with $20 \mu \mathrm{g} / \mathrm{mL}$ rTgRPP2. The cytokines TGF- $\beta 1$ and IL-10 related to immunosuppression and inflammation remained unchanged under $20 \mu \mathrm{g} / \mathrm{mL}$ rTgRPP2 incubation. Therefore, the administration dose of each mouse was determined to be $20 \mu \mathrm{g}$ per mouse, leading to final concentrations in peripheral blood of $20 \mu \mathrm{g} / \mathrm{mL}$ (peripheral blood represents approximately $5 \%$ of the total body weight of mice). The administration route is a key parameter for triggering effective immune protection by vaccines against $T$. gondii infections [61]. However, a successful vaccine against intracellular parasites should involve a preferable route, so intramuscular administration was selected in the present study. To some degree, the intramuscular route has been preferred as the first choice for investigating immune protection in many studies [62-65]. Due to a lack of synergy in the vaccine studies of $T$. gondii, the immunization strategy varies in different studies. In the present study, both the primary and secondary immunization triggered significantly higher antibodies (total IgG, IgG1, and IgG2a) and MHC molecules (MHC class I and II). However, such results did not reveal if animals vaccinated with one dose of rTgRPP2 could produce significant immune protection.

In vaccine development, the vaccine targets are of primary importance [66]. T. gondii has various life stages in the host and expresses different antigenic determinants during intracellular and extracellular stages, which shows good capacity in immune escape [67]. Faced with numerous antigenic determinants, gene sequence and three-dimensional conformation were mainly used to predict the potential targets $[68,69]$. However, compared with prediction, in vitro trials are superior. The in vitro results showed rTgRPP2 could regulate the functions of macrophages, indicating the antimicrobial activities of macrophages were promoted in vivo. Hence, in the subsequent trials, the mice were immunized with rTgRPP2 to investigate immune protection in vivo.

The important role of specific antibodies has been proven as the most critical indicator for evaluating adaptive immunogenicity against toxoplasmosis [70,71]. The obtained results indicate that specific antibodies against $T$. gondii can be induced by recombinant TgRPP2, whereas their titers relied on the immunization times. A Th1-biased immune response is essential for effectively resisting the replication of T. gondii [72], and the cell- or humoral-mediated immune responses can be evaluated by the ratio of IgG1 and IgG2a antibody titers [73]. In the present study, the antibody titers of IgG1 and IgG2a were obtained from the sera of mice immunized with rTgRPP2, emphasizing that the Th1- and Th2-biased immune responses were activated due to the higher levels of IgG1 and IgG2a. Previous studies have also investigated the types of immune response and obtained variable results. Predominant IgG1 synthesis was evaluated [74] by immunizations with recombinant rhoptry protein (ROP) 5 and ROP18. However, the observations revealed by [60] were different, indicating a predominant Th1-biased immune response when immunizing mice with recombinant ROP5. The possible reasons for this may be related to the different types of adjuvant, administration procedure, and even the immunization dosage.

Activated by $\mathrm{MHC}$ molecules, $\mathrm{CD}^{+}$and $\mathrm{CD} 8^{+} \mathrm{T}$-cell-mediated cell responses are important for suppressing the replication of intracellular parasite T. gondii [75,76]. Antigens presented by MHC class I molecules are mainly endogenous, which can result in strong $\mathrm{CD}^{+}$T-cell-mediated immune responses [77]. The MHC class II molecules can present more exogenous antigens to $\mathrm{CD} 4^{+} \mathrm{T}$-cells, which can induce stronger immune responses 
in resisting $T$. gondii [76]. The flow cytometry analysis in the present study revealed that animals immunized with recombinant TgRPP2 could generate significantly higher levels of MHC class I and II molecules, indicating that endogenous and exogenous antigen presentation was activated. These results also suggest that exogenous recombinant protein ( $\mathrm{rTgRPP}$ ) could be processed into an antigen peptide and presented to T-cells through the endogenous and exogenous antigen-presenting pathway. In summary, the results reveal that $r$ TgRPP2 is a potential molecular target for vaccines.

As illustrated above, cytokines play an essential role in $T$. gondii resistance via the activation of innate and adaptive immunity $[78,79]$. Activated innate immunity could further stimulate adaptive immunity, resulting in the clearance of intracellular parasites such as T. gondii and, eventually, the development of chronic infection [18]. In the in vivo experiment, the secretion of cytokines IFN- $\gamma$ and IL-4 was significantly promoted, confirming the Th1- and Th2-biased immune responses. In addition, a previous report reported that the early death of animals infected with acute toxoplasmosis was induced by strong immunity rather than the parasites [80]. Therefore, the secretion of IL-10 cytokines is important. Our studies indicated that IL-10 secretion was significantly enhanced after the second immunization, whereas IL-17 secretion remained constant. These findings indicate that animals vaccinated with $20 \mu \mathrm{g}$ rTgRPP2 could not yield intense immunosuppression and inflammation and lend credibility to the conclusion that the innate immune system can be activated to oppose the invasion of $T$. gondii.

A direct way to analyze the immune protection of rTgRPP2 is to apply the survival rate of immunized animals against $T$. gondii [81]. In the acute infection model, all challenged mice died of toxoplasmosis, whereas animals immunized with rTgRPP2 revealed significantly longer survival times, demonstrating that $\mathrm{rTgRPP} 2$ could provide partial immunity against virulent RH strains of $T$. gondii. The RH strain belonging to $T$. gondii type I (including the GT1 strain) can be isolated from humans and is considered the most virulent lineage in mice $[82,83]$. As an opportunistic parasite, $T$. gondii can survive in a healthy body and develop into chronic infections, whereas a devastating sequence can be caused in patients with a lower immunity [84]. Further research should evaluate the immune protection of rTgRPP2 in chronic infection individuals.

\section{Conclusions}

Our study is the first to reveal that recombinant TgRPP2 is recognized by murine Ana- 1 macrophages and the adherence of rTgRPP2 to Ana- 1 cells leads to a series of inflammatory responses that may potentially upregulate the immune response to remove pathogens. The interaction of rTgRPP2 could enhance the immune system to generate antibodies (total IgG and subclass IgG1 and IgG2a), cytokines (IFN- $\gamma$, IL-4, and IL-10), and MHC molecules (MHC I and II), along with prolonged survival time. The in vivo experiments indicated that partial immune protection against toxoplasmosis could be provided by immunization with recombinant TgRPP2, indicating that $\mathrm{rTgRPP} 2$ could be a candidate for the development of a vaccine and drugs against the replication of $T$. gondii.

Supplementary Materials: The following are available online at https: / www.mdpi.com/article / 10.3390/vaccines9040357/s1. Figure S1: The results of double digestion and sequence alignment; (a) double digestion analysis of recombinant plasmid pET32a/TgRPP2; Lane M: DNA molecular weight marker DL5000; Line 1: pET32a/TgRPP2 plasmid after double digestion; (b) Sequence alignment results of recombinant plasmid pET32a/RPP2; compared with the nucleotide sequences of the RPP2 gene (Genbank: XM_002364187), sequence analysis was conducted through the Blast program online (https: / / blast.ncbi.nlm.nih.gov / Blast.cgi, accessed on 6 April 2021). Table S1: Determination of total IgG in the sera of the immunized mice on Days 0,7, and 14; results were evaluated using one-way ANOVA analysis, followed by Dunnett's test, and shown as the mean of OD450 \pm standard deviation. Table S2: Determination of subclasses IgG1 and IgG2a in the sera of the immunized mice at Days 0, 7, and 14; results were evaluated using one-way ANOVA analysis, followed by Dunnett's test, and shown as the mean of OD450 \pm standard deviation. 
Author Contributions: Conceptualization, X.L.; methodology, Z.Y.; validation, Y.L.; formal analysis, Z.Y.; investigation, Z.Y., Y.L., Z.L. and M.T.A.; writing—original draft preparation, Z.Y.; writingreview and editing, Z.Y. and M.T.A.; project administration, R.Y., X.S., L.X. and X.L.; funding acquisition, J.L. (Junlong Liu) and J.L. (Jianxun Luo). All authors have read and agreed to the published version of the manuscript.

Funding: This research was funded by the Key Scientific and Technological Project of XPCC (2020AB025). The APC was funded by the State Key Laboratory of Veterinary Etiological Biology, Lanzhou Veterinary Research Institute, Chinese Academy of Agricultural Sciences.

Institutional Review Board Statement: Regarding the animals included in our research, this study followed the guidelines of the Animal Ethics Committee, Nanjing Agricultural University, China. The approval ID was PZ2019010.

Informed Consent Statement: Not applicable.

Data Availability Statement: The data presented in this study are available within the article and Supplementary Material.

Acknowledgments: We gratefully thank Haifeng Sun from the MOA Key Laboratory of Animal Bacteriology, Nanjing Agricultural University, Nanjing, PR China, for technical assistance with flow cytometry.

Conflicts of Interest: The authors declare no conflict of interest.

\section{References}

1. Zheng, J.; Cheng, Z.; Jia, H.; Zheng, Y. Characterization of aspartyl aminopeptidase from Toxoplasma gondii. Sci. Rep. 2016, 6, 34448. [CrossRef]

2. Dubey, J.P. History of the discovery of the life cycle of Toxoplasma gondii. Int. J. Parasitol. 2009, 39, 877-882. [CrossRef] [PubMed]

3. Montoya, J.G.; Liesenfeld, O. Toxoplasmosis. Lancet 2004, 363, 1965-1976. [CrossRef]

4. Jeffers, V.; Tampaki, Z.; Kim, K.; Sullivan, W.J., Jr. A latent ability to persist: Differentiation in Toxoplasma gondii. Cell Mol. Life Sci. 2018, 75, 2355-2373. [CrossRef] [PubMed]

5. Ahmadpour, E.; Daryani, A.; Sharif, M.; Sarvi, S.; Aarabi, M.; Mizani, A.; Rahimi, M.T.; Shokri, A. Toxoplasmosis in immunocompromised patients in Iran: A systematic review and meta-analysis. J. Infect. Dev. Countr. 2014, 8, 1503-1510. [CrossRef]

6. Sroka, J.; Bilska-Zajac, E.; Wojcik-Fatla, A.; Zajac, V.; Dutkiewicz, J.; Karamon, J.; Piotrowska, W.; Cencek, T. Detection and Molecular Characteristics of Toxoplasma gondii DNA in Retail Raw Meat Products in Poland. Foodborne Pathog. Dis. 2019, 16, 195-204. [CrossRef]

7. Marques, C.S.; Sousa, S.; Castro, A.; da Costa, J.M.C. Detection of Toxoplasma gondii oocysts in fresh vegetables and berry fruits. Parasit. Vectors 2020, 13, 180. [CrossRef] [PubMed]

8. Hernandez-Cortazar, I.B.; Acosta-Viana, K.Y.; Guzman-Marin, E.; Ortega-Pacheco, A.; Segura-Correa, J.C.; Jimenez-Coello, M. Presence of Toxoplasma gondii in Drinking Water from an Endemic Region in Southern Mexico. Foodborne Pathog. Dis. 2017, 14, 288-292. [CrossRef]

9. Khan, K.; Khan, W. Congenital toxoplasmosis: An overview of the neurological and ocular manifestations. Parasitol. Int. 2018, 67, 715-721. [CrossRef]

10. Olariu, T.R.; Remington, J.S.; McLeod, R.; Alam, A.; Montoya, J.G. Severe congenital toxoplasmosis in the United States: Clinical and serologic findings in untreated infants. Pediatr. Infect. Dis. J. 2011, 30, 1056-1061. [CrossRef]

11. Fallahi, S.; Rostami, A.; Nourollahpour Shiadeh, M.; Behniafar, H.; Paktinat, S. An updated literature review on maternal-fetal and reproductive disorders of Toxoplasma gondii infection. J. Gynecol. Obstet. Hum. Reprod. 2018, 47, 133-140. [CrossRef]

12. Brown, A.S.; Schaefer, C.A.; Quesenberry, C.P., Jr.; Liu, L.; Babulas, V.P.; Susser, E.S. Maternal exposure to toxoplasmosis and risk of schizophrenia in adult offspring. Am. J. Psychiatry 2005, 162, 767-773. [CrossRef] [PubMed]

13. Buxton, D.; Innes, E.A. A commercial vaccine for ovine toxoplasmosis. Parasitology 1995, 110, S11-S16. [CrossRef]

14. Dittmar, A.J.; Drozda, A.A.; Blader, I.J. Drug Repurposing Screening Identifies Novel Compounds That Effectively Inhibit Toxoplasma gondii Growth. Msphere 2016, 1, e00042-15. [CrossRef]

15. Lyons, R.E.; McLeod, R.; Roberts, C.W. Toxoplasma gondii tachyzoite-bradyzoite interconversion. Trends Parasitol. 2002, 18, 198-201. [CrossRef]

16. Ben-Harari, R.R.; Goodwin, E.; Casoy, J. Adverse Event Profile of Pyrimethamine-Based Therapy in Toxoplasmosis: A Systematic Review. Drugs R D 2017, 17, 523-544. [CrossRef] [PubMed]

17. Mandelbrot, L.; Kieffer, F.; Sitta, R.; Laurichesse-Delmas, H.; Winer, N.; Mesnard, L.; Berrebi, A.; Le Bouar, G.; Bory, J.P.; Cordier, A.G.; et al. Prenatal therapy with pyrimethamine + sulfadiazine vs spiramycin to reduce placental transmission of toxoplasmosis: A multicenter, randomized trial. Am. J. Obstet. Gynecol. 2018, 219, 386.e1-386.e9. [CrossRef] [PubMed]

18. Sasai, M.; Pradipta, A.; Yamamoto, M. Host immune responses to Toxoplasma gondii. Int. Immunol. 2018, 30, 113-119. [CrossRef] 
19. Liu, Y.C.; Zou, X.B.; Chai, Y.F.; Yao, Y.M. Macrophage polarization in inflammatory diseases. Int. J. Biol. Sci. 2014, 10, 520-529. [CrossRef] [PubMed]

20. Labonte, A.C.; Tosello-Trampont, A.C.; Hahn, Y.S. The role of macrophage polarization in infectious and inflammatory diseases. Mol Cells 2014, 37, 275-285. [CrossRef]

21. Gordon, S.; Taylor, P.R. Monocyte and macrophage heterogeneity. Nat. Rev. Immunol. 2005, 5, 953-964. [CrossRef]

22. Gordon, S. Alternative activation of macrophages. Nat. Rev. Immunol. 2003, 3, 23-35. [CrossRef] [PubMed]

23. Liu, X.; Li, J.; Peng, X.; Lv, B.; Wang, P.; Zhao, X.; Yu, B. Geraniin Inhibits LPS-Induced THP-1 Macrophages Switching to M1 Phenotype via SOCS1/NF-kB Pathway. Inflammation 2016, 39, 1421-1433. [CrossRef]

24. Ndao, O.; Puech, P.H.; Berard, C.; Limozin, L.; Rabhi, S.; Azas, N.; Dubey, J.P.; Dumetre, A. Dynamics of Toxoplasma gondii Oocyst Phagocytosis by Macrophages. Front. Cell Infect. Microbiol. 2020, 10, 207. [CrossRef] [PubMed]

25. Park, J.; Hunter, C.A. The role of macrophages in protective and pathological responses to Toxoplasma gondii. Parasite Immunol. 2020, 42, e12712. [CrossRef] [PubMed]

26. Barragan, A.; Sibley, L.D. Transepithelial migration of Toxoplasma gondii is linked to parasite motility and virulence. J. Exp. Med. 2002, 195, 1625-1633. [CrossRef] [PubMed]

27. Lambert, H.; Hitziger, N.; Dellacasa, I.; Svensson, M.; Barragan, A. Induction of dendritic cell migration upon Toxoplasma gondii infection potentiates parasite dissemination. Cell Microbiol. 2006, 8, 1611-1623. [CrossRef] [PubMed]

28. Tchórzewski, M. The acidic ribosomal P proteins. Int. J. Biochem. Cell Biol. 2002, 34, 911-915. [CrossRef]

29. Lacombe, A.; Maclean, A.E.; Ovciarikova, J.; Tottey, J.; Muhleip, A.; Fernandes, P.; Sheiner, L. Identification of the Toxoplasma gondii mitochondrial ribosome, and characterisation of a protein essential for mitochondrial translation. Mol. Microbiol. 2019, 112, 1235-1252. [CrossRef]

30. Nilsen, A.; LaCrue, A.N.; White, K.L.; Forquer, I.P.; Cross, R.M.; Marfurt, J.; Mather, M.W.; Delves, M.J.; Shackleford, D.M.; Saenz, F.E.; et al. Quinolone-3-diarylethers: A new class of antimalarial drug. Sci. Transl. Med. 2013, 5, 177ra137. [CrossRef]

31. Phillips, M.A.; Lotharius, J.; Marsh, K.; White, J.; Dayan, A.; White, K.L.; Njoroge, J.W.; El Mazouni, F.; Lao, Y.; Kokkonda, S.; et al. A long-duration dihydroorotate dehydrogenase inhibitor (DSM265) for prevention and treatment of malaria. Sci. Transl. Med. 2015, 7, 296ra111. [CrossRef] [PubMed]

32. Ke, H.; Mather, M.W. + Targeting Mitochondrial Functions as Antimalarial Regime, What Is Next? Curr. Clin. Micro Rpt. 2017, 4, 175-191. [CrossRef]

33. Sudarsan, R.; Chopra, R.K.; Khan, M.A.; Sharma, S. Ribosomal protein P2 localizes to the parasite zoite-surface and is a target for invasion inhibitory antibodies in Toxoplasma gondii and Plasmodium falciparum. Parasitol. Int. 2015, 64, 43-49. [CrossRef] [PubMed]

34. Szuster-Ciesielska, A.; Wawiorka, L.; Krokowski, D.; Grankowski, N.; Jarosz, L.; Lisiecka, U.; Tchorzewski, M. Immunogenic Evaluation of Ribosomal P-Protein Antigen P0, P1, and P2 and Pentameric Protein Complex P0-(P1-P2) 2 of Plasmodium falciparum in a Mouse Model. J. Immunol. Res. 2019, 2019, 9264217. [CrossRef] [PubMed]

35. Das, S.; Basu, H.; Korde, R.; Tewari, R.; Sharma, S. Arrest of nuclear division in Plasmodium through blockage of erythrocyte surface exposed ribosomal protein P2. PLoS Pathog. 2012, 8, e1002858. [CrossRef]

36. Mishra, P.; Dmello, C.; Sengupta, D.; Chandrabhan Singh, S.; Kirkise, N.; Hosur, R.V.; Sharma, S. Molecular study of binding of Plasmodium ribosomal protein P2 to erythrocytes. Biochimie 2020, 176, 181-191. [CrossRef]

37. Lamarque, M.; Besteiro, S.; Papoin, J.; Roques, M.; Vulliez-Le Normand, B.; Morlon-Guyot, J.; Dubremetz, J.F.; Fauquenoy, S.; Tomavo, S.; Faber, B.W.; et al. The RON2-AMA1 interaction is a critical step in moving junction-dependent invasion by apicomplexan parasites. PLoS Pathog. 2011, 7, e1001276. [CrossRef] [PubMed]

38. Guang-Wei, Z.; Bo, S.; Qing, X.; Li-Xin, X.U.; Ruo-Feng, Y.; Xiao-Kai, S.; Adam, H.I.; Xiang-Rui, L.I. Isolation and Molecular Characterization of Toxoplasma gondii from Chickens in China. J. Integr. Agric. 2012, 11, 1347-1353. [CrossRef]

39. Hassan, I.A.; Wang, S.; Xu, L.; Yan, R.; Song, X.; Li, X. Immunoglobulin and cytokine changes induced following immunization with a DNA vaccine encoding Toxoplasma gondii selenium-dependent glutathione reductase protein. Exp. Parasitol. 2014, 146, 1-10. [CrossRef] [PubMed]

40. Song, H.; Yan, R.; Xu, L.; Song, X.; Shah, M.A.; Zhu, H.; Li, X. Efficacy of DNA vaccines carrying Eimeria acervulina lactate dehydrogenase antigen gene against coccidiosis. Exp. Parasitol. 2010, 126, 224-231. [CrossRef] [PubMed]

41. Green, L.C.; Wagner, D.A.; Glogowski, J.; Skipper, P.L.; Wishnok, J.S.; Tannenbaum, S.R. Analysis of nitrate, nitrite, and [ ${ }^{15}$ N]nitrate in biological fluids. Anal. Biochem. 1982, 126, 131-138. [CrossRef]

42. Tang, X.M.; Yin, G.W.; Qin, M.; Tao, G.R.; Suo, J.X.; Liu, X.Y.; Suo, X. Transgenic Eimeria tenella as a vaccine vehicle: Expressing TgSAG1 elicits protective immunity against Toxoplasma gondii infections in chickens and mice. Sci. Rep.-Uk 2016, 6, 29379. [CrossRef] [PubMed]

43. Di Carlo, F.J.; Fiore, J.V. On the composition of zymosan. Science 1958, 127, 756-757. [CrossRef] [PubMed]

44. Mosser, D.M.; Edwards, J.P. Exploring the full spectrum of macrophage activation. Nat. Rev. Immunol. 2008, 8, 958-969. [CrossRef]

45. Mantovani, A.; Biswas, S.K.; Galdiero, M.R.; Sica, A.; Locati, M. Macrophage plasticity and polarization in tissue repair and remodelling. J. Pathol. 2013, 229, 176-185. [CrossRef] [PubMed]

46. Brunet, J.; Pfaff, A.W.; Abidi, A.; Unoki, M.; Nakamura, Y.; Guinard, M.; Klein, J.P.; Candolfi, E.; Mousli, M. Toxoplasma gondii exploits UHRF1 and induces host cell cycle arrest at G2 to enable its proliferation. Cell Microbiol. 2008, 10, 908-920. [CrossRef] [PubMed] 
47. Lavine, M.D.; Arrizabalaga, G. Induction of mitotic S-phase of host and neighboring cells by Toxoplasma gondii enhances parasite invasion. Mol. Biochem. Parasitol. 2009, 164, 95-99. [CrossRef] [PubMed]

48. Kim, M.J.; Jung, B.K.; Cho, J.; Song, H.; Pyo, K.H.; Lee, J.M.; Kim, M.K.; Chai, J.Y. Exosomes Secreted by Toxoplasma gondii-Infected L6 Cells: Their Effects on Host Cell Proliferation and Cell Cycle Changes. Korean J. Parasitol. 2016, 54, 147-154. [CrossRef] [PubMed]

49. Liu, X.C.; Li, X.Y.; Wang, Q.Q.; Sun, X.N.; Lu, M.M.; Ehsan, M.; Xu, L.X.; Yan, R.F.; Song, X.K.; Li, X.R. Toxoplasma gondii Histone 4 Affects Some Functions of Murine Ana-1 Macrophages In Vitro. J. Eukaryot. Microbiol. 2018, 65, 860-869. [CrossRef] [PubMed]

50. Mammari, N.; Halabi, M.A.; Yaacoub, S.; Chlala, H.; Dardé, M.L.; Courtioux, B. Toxoplasma gondii Modulates the Host Cell Responses: An Overview of Apoptosis Pathways. Biomed. Res. Int. 2019, 2019, 6152489. [CrossRef]

51. D'Arcy, M.S. Cell death: A review of the major forms of apoptosis, necrosis and autophagy. Cell Biol Int 2019, 43, 582-592. [CrossRef] [PubMed]

52. Xu, X.; Lai, Y.; Hua, Z.C. Apoptosis and apoptotic body: Disease message and therapeutic target potentials. Biosci. Rep. 2019, 39, BSR20180992. [CrossRef]

53. Payne, T.M.; Molestina, R.E.; Sinai, A.P. Inhibition of caspase activation and a requirement for NF- $\mathrm{kB}$ function in the Toxoplasma gondii-mediated blockade of host apoptosis. J. Cell. Sci. 2003, 116, 4345-4358. [CrossRef] [PubMed]

54. Goebel, S.; Luder, C.G.; Gross, U. Invasion by Toxoplasma gondii protects human-derived HL-60 cells from actinomycin D-induced apoptosis. Med. Microbiol. Immunol. 1999, 187, 221-226. [CrossRef] [PubMed]

55. Medina, C.B.; Mehrotra, P.; Arandjelovic, S.; Perry, J.S.A.; Guo, Y.; Morioka, S.; Barron, B.; Walk, S.F.; Ghesquière, B.; Krupnick, A.S.; et al. Metabolites released from apoptotic cells act as tissue messengers. Nature 2020, 580, 130-135. [CrossRef] [PubMed]

56. Petrovsky, N.; Aguilar, J.C. Vaccine adjuvants: Current state and future trends. Immunol. Cell Biol. 2004, 82, 488-496. [CrossRef] [PubMed]

57. Brake, D.A. Vaccinology for control of apicomplexan parasites: A simplified language of immune programming and its use in vaccine design. Int. J. Parasitol. 2002, 32, 509-515. [CrossRef]

58. Qu, D.F.; Han, J.Z.; Du, A.F. Enhancement of protective immune response to recombinant Toxoplasma gondii ROP18 antigen by ginsenoside Re. Exp. Parasitol. 2013, 135, 234-239. [CrossRef] [PubMed]

59. Sanchez, V.R.; Pitkowski, M.N.; Cuppari, A.V.F.; Rodriguez, F.M.; Fenoy, I.M.; Frank, F.M.; Goldman, A.; Corral, R.S.; Martin, V. Combination of CpG-oligodeoxynucleotides with recombinant ROP2 or GRA4 proteins induces protective immunity against Toxoplasma gondii infection. Exp. Parasitol. 2011, 128, 448-453. [CrossRef] [PubMed]

60. Zheng, B.; Lu, S.H.; Tong, Q.B.; Kong, Q.M.; Lou, D. The virulence-related rhoptry protein 5 (ROP5) of Toxoplasma gondii is a novel vaccine candidate against toxoplasmosis in mice. Vaccine 2013, 31, 4578-4584. [CrossRef] [PubMed]

61. Wang, T.; Yin, H.Q.; Li, Y.; Zhao, L.Z.; Sun, X.H.; Cong, H. Vaccination with recombinant adenovirus expressing multi-stage antigens of Toxoplasma gondii by the mucosal route induces higher systemic cellular and local mucosal immune responses than with other vaccination routes. Parasite 2017, 24, 12. [CrossRef]

62. Chen, J.; Zhou, D.H.; Li, Z.Y.; Petersen, E.; Huang, S.Y.; Song, H.Q.; Zhu, X.Q. Toxoplasma gondii: Protective immunity induced by rhoptry protein 9 (TgROP9) against acute toxoplasmosis. Exp. Parasitol. 2014, 139, 42-48. [CrossRef]

63. Sonaimuthu, P.; Ching, X.T.; Fong, M.Y.; Kalyanasundaram, R.; Lau, Y.L. Induction of Protective Immunity against Toxoplasmosis in BALB/c Mice Vaccinated with Toxoplasma gondii Rhoptry-1. Front Microbiol. 2016, 7, 808. [CrossRef]

64. Ghaffarifar, F.; Jafarimodrek, M.; Vazini, H.; Sharifi, Z.; Dalimi, A.; Dayer, M.S. Assessment of DNA vaccine encoding Toxoplasma gondii microneme complete gene and IL-12 as adjuvant in BALB/c mice. Iran J. Basic Med. Sci. 2019, 22, 901-907. [CrossRef] [PubMed]

65. Wu, M.M.; An, R.; Chen, Y.; Chen, T.Y.; Wen, H.Y.; Yan, Q.; Shen, J.L.; Chen, L.J.; Du, J. Vaccination with recombinant Toxoplasma gondii CDPK3 induces protective immunity against experimental toxoplasmosis. Acta Trop. 2019, 199, 105148. [CrossRef] [PubMed]

66. Stern, P.L. Key steps in vaccine development. Ann. Allergy Asthma Immunol. 2020, 125, 17-27. [CrossRef] [PubMed]

67. Wipasa, J.; Riley, E.M. The immunological challenges of malaria vaccine development. Expert Opin. Biol. Ther. 2007, 7, 1841-1852. [CrossRef]

68. Penner, R.C. Backbone Free Energy Estimator Applied to Viral Glycoproteins. J. Comput. Biol. 2020, 27, 1495-1508. [CrossRef]

69. Sanchez-Trincado, J.L.; Gomez-Perosanz, M.; Reche, P.A. Fundamentals and Methods for T- and B-Cell Epitope Prediction. J. Immunol. Res. 2017, 2017, 2680160. [CrossRef]

70. Correa, D.; Canedo-Solares, I.; Ortiz-Alegria, L.B.; Caballero-Ortega, H.; Rico-Torres, C.P. Congenital and acquired toxoplasmosis: Diversity and role of antibodies in different compartments of the host. Parasite Immunol. 2007, 29, 651-660. [CrossRef] [PubMed]

71. Kang, H.; Remington, J.S.; Suzuki, Y. Decreased resistance of B cell-deficient mice to infection with Toxoplasma gondii despite unimpaired expression of IFN-gamma, TNF-alpha, and inducible nitric oxide synthase. J. Immunol. 2000, 164, $2629-2634$. [CrossRef]

72. Sayles, P.C.; Gibson, G.W.; Johnson, L.L. B cells are essential for vaccination-induced resistance to virulent Toxoplasma gondii. Infect. Immun. 2000, 68, 1026-1033. [CrossRef] [PubMed] 
73. Wang, J.L.; Elsheikha, H.M.; Zhu, W.N.; Chen, K.; Li, T.T.; Yue, D.M.; Zhang, X.X.; Huang, S.Y.; Zhu, X.Q. Immunization with Toxoplasma gondii GRA17 Deletion Mutant Induces Partial Protection and Survival in Challenged Mice. Front. Immunol. 2017, 8, 730. [CrossRef]

74. Grzybowski, M.M.; Dziadek, B.; Gatkowska, J.M.; Dzitko, K.; Dlugonska, H. Towards vaccine against toxoplasmosis: Evaluation of the immunogenic and protective activity of recombinant ROP5 and ROP18 Toxoplasma gondii proteins. Parasitol. Res. 2015, 114, 4553-4563. [CrossRef] [PubMed]

75. Kugler, D.G.; Mittelstadt, P.R.; Ashwell, J.D.; Sher, A.; Jankovic, D. CD4(+) T cells are trigger and target of the glucocorticoid response that prevents lethal immunopathology in toxoplasma infection. J. Exp. Med. 2013, 210, 1919-1927. [CrossRef] [PubMed]

76. Dupont, C.D.; Christian, D.A.; Selleck, E.M.; Pepper, M.; Leney-Greene, M.; Harms Pritchard, G.; Koshy, A.A.; Wagage, S.; Reuter, M.A.; Sibley, L.D.; et al. Parasite fate and involvement of infected cells in the induction of CD4 ${ }^{+}$and CD8 ${ }^{+} \mathrm{T}_{\text {cell responses }}$ to Toxoplasma gondii. PLoS Pathog. 2014, 10, e1004047. [CrossRef] [PubMed]

77. Lyons, R.E.; Anthony, J.P.; Ferguson, D.J.; Byrne, N.; Alexander, J.; Roberts, F.; Roberts, C.W. Immunological studies of chronic ocular toxoplasmosis: Up-regulation of major histocompatibility complex class I and transforming growth factor beta and a protective role for interleukin-6. Infect. Immun. 2001, 69, 2589-2595. [CrossRef]

78. Sturge, C.R.; Benson, A.; Raetz, M.; Wilhelm, C.L.; Mirpuri, J.; Vitetta, E.S.; Yarovinsky, F. TLR-independent neutrophil-derived IFN- $\gamma$ is important for host resistance to intracellular pathogens. Proc. Natl. Acad. Sci. USA 2013, 110, 10711-10716. [CrossRef] [PubMed]

79. Matowicka-Karna, J.; Dymicka-Piekarska, V.; Kemona, H. Does Toxoplasma gondii Infection Affect the Levels of IgE and Cytokines (IL-5, IL-6, IL-10, IL-12, and TNF-alpha)? Clin. Dev. Immunol. 2009, 2009, 374696. [CrossRef]

80. Ching, X.T.; Fong, M.Y.; Lau, Y.L. Evaluation of Immunoprotection Conferred by the Subunit Vaccines of GRA2 and GRA5 against Acute Toxoplasmosis in BALB/c Mice. Front. Microbiol. 2016, 7, 609. [CrossRef] [PubMed]

81. Zheng, B.; Ding, J.; Chen, X.; Yu, H.; Lou, D.; Tong, Q.; Kong, Q.; Lu, S. Immuno-Efficacy of a T. gondii Secreted Protein with an Altered Thrombospondin Repeat (TgSPATR) As a Novel DNA Vaccine Candidate against Acute Toxoplasmosis in BALB/c Mice. Front. Microbiol. 2017, 8, 216. [CrossRef] [PubMed]

82. Dubey, J.P. Mouse pathogenicity of Toxoplasma gondii isolated from a goat. Am. J. Vet. Res. 1980, 41, 427-429. [PubMed]

83. Howe, D.K.; Honore, S.; Derouin, F.; Sibley, L.D. Determination of genotypes of Toxoplasma gondii strains isolated from patients with toxoplasmosis. J. Clin. Microbiol. 1997, 35, 1411-1414. [CrossRef] [PubMed]

84. Melchor, S.J.; Ewald, S.E. Disease Tolerance in Toxoplasma Infection. Front. Cell Infect. Microbiol. 2019, 9, 185. [CrossRef] [PubMed] 